\title{
THIAMIN AND NIACIN IN RUMINANT NUTRITION
}

\author{
JOHEIN HARMEYER AND UWE KOLLENKIRCHEN \\ Institute of Physiology, School of Veterinary Medicine, D-3000 Hannover 1, West \\ Germany
}

CONTENTS

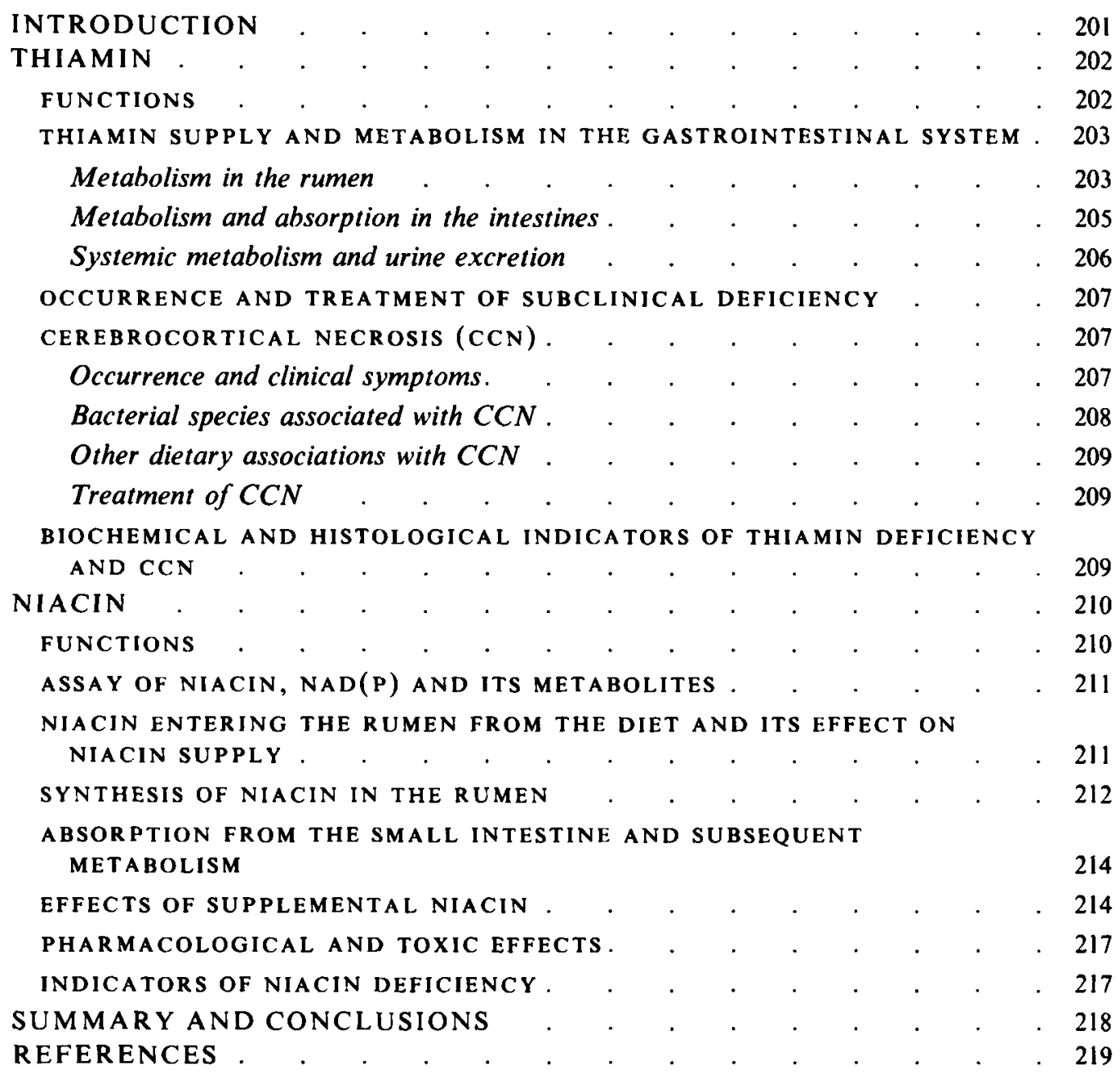

\section{INTRODUCTION}

Mechanisms of absorption, post-absorptive transport, metabolic activation, catabolism and excretion of B-vitamins are in general similar in ruminants and non-ruminants.

The mature ruminant animal is capable of synthesizing all B-vitamins including choline and inositol in its gastrointestinal (GI) system, and at moderate levels of production is 
capable of satisfying its B-vitamin requirement entirely from synthesis in the rumen and intestine (Virtanen, 1963). Because of the varying extent of GI tract synthesis the B-vitamin status of the ruminant animal cannot be deduced from measurements of the B-vitamin content of the diet, and unequivocal thiamin and niacin deficiencies cannot generally be produced by giving diets low in those vitamins. Indeed, the occurrence of the uncomplicated deficiency disorders, such as are found in simple-stomached animals, are controversial for thiamin and unknown for niacin. The same is not true for preruminant animals which behave like non-ruminants.

Marginal B-vitamin deficiencies may, however, occur in mature ruminants when requirements of B-vitamins are high or when decreased microbial synthesis or increased destruction of B-vitamins occurs in the rumen. Such conditions have been reported in the high-performing dairy cow, in fattening cattle and sheep, and in animals on pasture, consuming plants which contain antivitamins. Deficiencies may also occur in animals on diets which lead to microbial production of vitamin-destroying activities in the rumen and in animals receiving certain food additives and drugs (antibiotics or anthelmintics; Miller et al. 1983d, 1986a). Occurrence of such marginal deficiencies is, however, difficult to establish. Clear-cut clinical symptoms or biochemical criteria of a B-vitamin deficiency do not usually develop before the deficiency is severe. When the supply of a B-vitamin is merely suboptimal diagnosis relies on assessment of general performance, such as rate of growth, weight gain, milk yield or reduction of dry matter (DM) digestion; the smaller the degree of inadequacy of a B-vitamin supply the less sensitive these indicators become. Furthermore, subclinical symptoms are often complicated by deficiencies of other nutrients and by other uncontrollable variables. Thiamin deficiency in the rumen, for example, may significantly depress microbial protein synthesis (Candau \& Kone, 1980), which per se may result in poor growth. The nutritional and environmental factors which are suspected of limiting the animals' performance through a marginal B-vitamin deficiency are often poorly understood. Improvements in general performance with a B-vitamin supplement are reported in one feeding trial. But the effects can sometimes not be verified in subsequent trials at other places or at the same place in another year (Harmeyer \& Grabe, 1981; Günther, 1987; Grosse-Holz \& Harmeyer, 1988).

\section{THIAMIN \\ FUNCTIONS}

The biologically active form of the vitamin $B_{1}$ coenzyme (previously aneurin) in energy metabolism is thiamin pyrophosphate (TPP) (Fig. 1) which acts in the irreversible decarboxylation reactions (cocarboxylase) of $\alpha$-ketoacids (pyruvate $\rightarrow$ acetyl-CoA or $\alpha$ ketoglutarate $\rightarrow$ succinyl-CoA) and in the transketolase reaction of the pentose phosphate cycle (ribulose-5-phosphate + ribose-5-phosphate $\rightarrow$ seduheptulose-7-phosphate + triose phosphate). The decarboxylation reactions are required for transfer of energy from glucose oxidation and from oxidation of non-essential amino acids via the citric acid cycle. The biochemical processes involved in the functions of the TPP-containing enzyme complex have been described (Koike \& Koike, 1982; Gubler, 1984). The pentose phosphate cycle is required for formation of pentoses.

Although energetic utilization of glucose is quantitatively less important for ruminants that for non-ruminants, pentoses are needed for nucleotide synthesis. Moreover, the pentose phosphate cycle contributes significantly to utilization of glucose by the mammary gland (Black et al. 1957) and brain (Smith \& Glascock, 1969). It is, however, uncertain whether intermediary utilization in ruminant brain, which probably differs from other tissues (Moss, 1964), is depressed during thiamin deficiency, as Thornber et al. (1981) found 


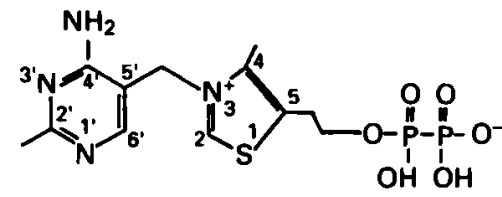

Fig. 1. Structure of thiaminpyrophosphate.

no differences in brain glucose uptake from measurements of arterio-venous differences between anaesthetized thiamin-deficient and control preruminant lambs. Dysfunctions of the central nervous system are, however, the major clinical symptoms of a diseased state in ruminants which is associated with thiamin deficiency, indicating that thiamin plays an important role in normal brain function. Since no convincing evidence has been presented that these symptoms are exerted through impaired energetic utilization of glucose, it is suggested that the functions of thiamin in the nervous system are at least partly mediated by mechanisms different from those exerted by the vitamin $B_{1}$ coenzyme. This assumption is based among other observations on the presence of a specific enzyme system in brain, ATP: thiamin-diphosphate phosphotransferase (EC 2.7.4.15), which catalyses the synthesis of thiamintriphosphate (TTP) from TPP (Cooper et al. 1982; Nishino \& Itokawa, 1983). The distinct function of TPP in brain is, however, still obscure. Some observations support the view that thiamin is required for normal brain transmitter functions. High affinity uptake of serotonin by synaptosomal cerebellar preparations from pyrithiamintreated thiamin-deficient rats were reduced by $40 \%$ compared to normal control rats. Conversely, high affinity uptakes of aspartate and glutamate, which also function as transmitters in brain, were selectively enhanced in these preparations. Vesicular uptake of serotonin by synaptosomes was markedly impaired and resulted in a significant increase in serotonin catabolism in cerebellar cortex. The cerebellar cortex is known to be directly involved in the control of motor functions (Plaitakis et al. 1982).

\section{THIAMIN SUPPLY AND METABOLISM IN THE GASTROINTESTINAL SYSTEM}

\section{Metabolism in the rumen}

The thiamin supply of the ruminant host is mainly determined by the apparent synthesis of thiamin in the reticulo-rumen. About $90 \%$ of the thiamin in the rumen is present in the particle-free rumen fluid as free thiamin, but mainly probably as TPP (Gerbaulet, 1979; Höller \& Breves, 1980), and is readily accessible to extracellular microbial thiaminases (Edwin \& Jackman, 1982). Daily flow of thiamin from the rumen into the duodenum of cattle and sheep fed on different diets ranged from 30 to $50 \mathrm{mg} / \mathrm{d}$ (cattle; Steinberg \& Kaufmann, 1977; Breves et al. 1981) and from 1.5 to $3.5 \mathrm{mg} / \mathrm{d}$ (sheep; Breves et al. 1980). Of the thiamin which reached the duodenum of sheep $90 \%$ was of microbial origin (Breves et al. 1980, 1981). Synthesis of thiamin in the rumen of sheep was positively related to duodenal flow of microbial protein and to volatile fatty acid (VFA) concentration in the rumen. Apparent synthesis of thiamin may be depressed either by reduction of microbial thiamin synthesis or by increased degradation. The type of grain, for example, was found to influence apparent microbial synthesis of thiamin in the rumen, but the cause of these changes is still unclear (Miller et al. $1983 b, c$ ). The need to take account of both synthesis and degradation of thiamin was indicated by the finding that reduction in microbial activity due to phosphorus depletion appeared to depress thiamin synthesis but not thiamin flow to the duodenum, implying a parallel reduction in thiaminase activity (Barschdorf, 1985). 
Two types of microbial thiaminase, I (EC 2.5.1.2) and II (EC 3.5.99.2), have been detected in rumen contents (Evans, 1975; Edwin \& Jackman, 1970, 1982). Under normal feeding conditions their activities in the rumen are usually small, allowing sufficient synthesis of thiamin to meet the animals' requirements (Brent \& Bartley, 1984). The two thiaminases degrade thiamin by different mechanisms. The exoenzyme thiaminase I catalyses nucleophilic displacement of the thiazole moiety from the methylene group by various other molecules and leads to the formation of thiamin derivatives. Its activity is strongly inhibited by thiamin or other primary substrates and stimulated by cosubstrates (secondary substrates) (Suzuki \& Ooba, 1973; Kazemi \& Brent 1985). Thiaminase II is a hydrolytic enzyme that splits the methylene- $\mathrm{N}$-thiazole bond to yield the pyrimidin and thiazole components (Fig. 2). Suitable cosubstrates (e.g. $\Delta$-1-pyrroline, cysteine, proline, hypotaurine, lysine and nicotinic acid) are required for the thiaminase I reaction to occur. These cosubstrates are believed to be ubiquitously present in rumen contents (Edwin et al. 1976a; Boyd \& Walton, 1977). It has been suggested that some of the thiamin derivatives after being absorbed from the GI tract may contribute to thiamin deficiency by competing with target cell thiamin-binding sites (thiamin antagonists) (Edwin et al. 1976 b). Although this has not yet been experimentally verified, it receives some support from the results of Mueller \& Asplund (1981).

In continuation of this assumption Brent \& Bartley (1984) suggested that prophylactic feeding of extra thiamin to animals with high thiaminase I activity might increase production of thiaminase antagonists and thereby precipitate cerebrocortical necrosis (CCN), but this appears unlikely since supplemental thiamin or supplementation with the thiamin antagonist, thiamin propyldisulphide, suppressed extracellular thiaminase I activity of Bacteroides thiaminolyticus in vitro (Suzuki \& Ooba, 1973; Thomas, 1986 ). There is also indication that rumen fluid from normal animals contains factors which inhibit thiaminase activity (Thomas, 1986 b). Another suggested cause of a deficient supply of thiamin to the host animal is the presence of certain thermostable anti-thiamin factors (for example, flavanoids mainly from bracken (Pteridium aquilinum) fern or dihydroxyphenoles) (Zintzen, 1973; Höller et al. 1976). These compounds interacted with thiamin to form reaction products (mostly disulphides) which could not be detected subsequently by standard fluorescence methods based on the oxidation of thiamin to thiochrome. At least some of these thiamin derivatives are probably still biologically available and feeding them to animals failed to induce thiamin deficiency (Edwin \& Jackman, 1982). It appears that they can be reconverted readily to the biologically active thiol form of the vitamin by biological reducing agents such as cysteine (Evans, 1975). Reactivation may take place in the rumen or in tissues.

Feed additives such as sulphates (e.g. gypsum) or antibiotics may also influence apparent thiamin production in the rumen. Thiamin was readily inactivated by sulphites which are produced as intermediary products by microbial reduction of sulphates (Zoltewicz et al. 1982). The production rate of sulphides in the rumen may vary considerably (J. Harmeyer, unpublished observation), possibly paralleled by changes in the redox potential. Low redox potentials also stabilized thiaminase against heat treatment and increased its activity, as verified by an approximately threefold increase in thiaminase activity after addition of $1 \mathrm{~mm}$-dithiothreitol to in vitro enzyme preparations (Thomas, 1986 b). It appears that increases in reduction properties of rumen contents, as indicated by a drop in redox potential, may lead to increased inactivation of thiamin in the rumen. Addition of ionophores or antibiotics to the rumen may also depress apparent thiamin synthesis (Höller et al. 1985; Lebzien et al. 1986), perhaps as a consequence of changes in microbial growth or redox potential. On the other hand, addition of monensin or chlortetracycline to diets high in concentrates have sometimes been shown to reduce the rate of thiamin destruction 


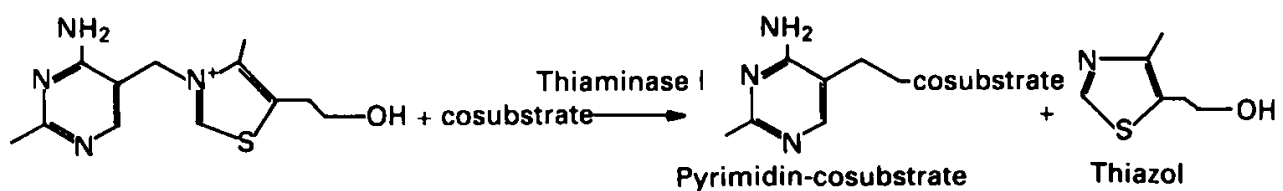

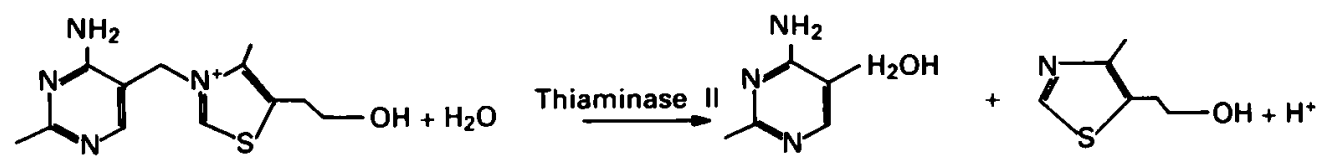

Fig. 2. Actions of thiaminases I (EC 2.5.1.2) and II (EC 3.5.99.2).

and to increase duodenal flow of thiamin (Miller et al. 1983a, 1986a). It appears that under these conditions apparent synthesis of thiamin in the rumen was already depressed by the high intake of concentrate. Increases in the amount of concentrates appear to reduce apparent thiamin synthesis in the rumen. This is supported by the observation that biochemical symptoms of subclinical thiamin deficiency increased in parallel with increase in milk yield (Bogin et al. 1985). Effects may be partly related to reduced $\mathrm{pH}$ values. Although thiamin is quite stable at lower $\mathrm{pH}$ values thiaminase activity in rumen microbial cultures increased after acid treatment (Brent \& Bartley, 1984; Thomas, 1986 $\mathrm{h}$ ). Diets which encourage rumen lactic acidosis are likely to create symptoms of thiamin deficiency, as verified by increases in erythrocyte transketolase (EC 2.2.1.1) activity (Clausen, 1977).

\section{Metabolism and absorption in the intestines}

Absorption of thiamin occurs mainly in the small intestine (Miller et al. 1986a,b). Earlier studies indicated absorption of thiamin from the rumen, but were not confirmed in subsequent studies with sheep and cows (Höller et al. 1977, 1979 b; Steinberg et al. 1977). Two mechanisms appear to be involved in intestinal uptake of thiamin; a carrier-mediated saturable process (Hoyumpa, 1982) which probably accounts for most of thiamin absorption at physiological lumen thiamin concentrations and a non-saturable diffusion process by which thiamin is apparently absorbed passively at higher lumen concentrations. Absorption is stimulated by the presence of essential free fatty acids (Zintzen, 1973), but for an unknown reason. It is also unknown whether any control is exerted on intestinal absorption of thiamin by the host animal.

Absorption of thiamin from the large intestine is usually small. Miller et al. (1986 b) found that about $12 \%$ of thiamin entering the perfused colon and rectum of sheep was absorbed, probably by a passive mechanism (Höller et al. 1982). Under normal feeding conditions it appeared that synthesis of thiamin in the large intestine of steers exceeded thiamin absorption as faecal thiamin exceeded that in ileal flow (Miller et al. 1986 b). In steers on diets containing high levels of maize, wheat, oats, barley or sorghum apparent thiamin absorption from the hind gut contributed 0-10\% to overall absorption of thiamin. The proportion of faecal thiamin deriving from synthesis in the large intestine probably varies with extent of hind gut fermentation and with relative activities of thiaminases present in the reticulo-rumen and in the hind gut (Wilson et al. 1984). No correlation has been reported between the amount of thiamin which enters the small intestine and faecal excretion of thiamin. It appears unlikely that such correlation exists for ruminants. Ruminant faeces may also contain thiaminase activity (Thomas, 1986a) which probably originates from microbial hind gut fermentation, since abomasal contents from sheep have been shown to contain no thiaminase activity (Wilson et al. 1984). In grazing sheep which 
were probably eating large amounts of poor quality roughage faecal thiaminase activity was positively related with poor growth and impaired general performance (Thomas, $1986 a$ ).

\section{Systemic metabolism and urine excretion}

The mechanisms of tissue uptake of thiamin from extracellular fluid do not seem to have been investigated. Entry of thiamin from blood into the cerebrospinal fluid was shown to take place via a saturable mechanism which is probably located in the chorioid plexus (Spector, 1982). Tissue uptake of thiamin from blood is highest by brain, heart, liver, kidney and lower by skeletal muscle (Nakajima, 1984). Disappearance of $\left[{ }^{35}\right.$ S]labelled thiamin from mature sheeps' blood, where it is probably bound to proteins (Frank et al. 1970), followed a three-compartment exponential curve with half-lives of $0.4,1.7$ and 103.5 min (Höller et al. 1979a; Breves et al. 1982). In other experiments with 10-d-old lambs blood thiamin decay curves were fitted to two exponential functions which yielded halflives of 4.7 and $7 \cdot 1 \mathrm{~min}$ (Thornber et al. 1981). The criteria applied for defining the number of compartments for the best fit of the data, however, were not unequivocally clear in these studies. Thiamin deficiency reduced the disappearance rate of thiamin from plasma by about $30 \%$, indicating a sparing mechanism for thiamin in the deficiency state (Thornber et al. 1981). Much longer half-lives of 10-20 d have been estimated in human blood for the thiamin compartment with slowest turnover (Zintzen, 1973). Applying these findings to ruminants would mean that possibly still another more slowly equilibrating, yet unidentified, compartment may also be present in ruminants. It appears, however, uncertain whether the slowly equilibrating compartment is of great physiological importance, since symptoms of thiamin deficiency can be produced in simple-stomached animals in a relatively short time by feeding thiamin-deficient diets. There is agreement that thiamin is not stored in particular organs and a continuous supply of thiamin is necessary. Thiamin turnover in brain is only $2-3 \% / \mathrm{h}$ (Spector, 1982) and appears to be very slow compared with other tissues.

From this, it appears that development of clinical and subclinical symptoms of thiamin deficiency for a given reduction in thiamin supply may be influenced by differences in thiamin turnover of the individual organs.

In rat tissue, thiamin was shown to be present as free thiamin, as mono-, pyro- and triphosphate and as disulphide. The phosphorylated compounds were degraded by mono-, pyro- and triphosphatases which have been identified in brain, heart, and kidney (Ogawa et al. 1982). TTP was quantitatively the most important form of thiamin in sheep brain (Thornber et al. 1980), where its concentration appeared to be less affected by the thiamin status of the animal than in other tissues. Autoradiographic studies with rat liver showed that about $50 \%$ of the intracellular thiamin was present in the cytosol, mainly as coenzyme, about $35 \%$ was in the mitochondria, $10 \%$ in the nuclear fraction, while the microsomes usually contained negligible amounts of intracellular thiamin (Harris et al. 1972; Gubler, 1984). It appears unlikely, however, that intracellular distribution of thiamin is the same in all tissues; it would be of interest to study this in brain tissue.

Thiamin excretion in ruminants via urine appears of little physiological or pathological significance. Excretion in milk, which normally contains between 0.5 and $0.8 \mathrm{mg}$ thiamin/1 in cows and 2.2-3.8 mg/l in sheep (Oracova \& Corner, 1960 ; Zintzen, 1973) may, however, contribute significantly to the thiamin balance. 


\section{OCCURRENCE AND TREATMENT OF SUBCLINICAL DEFICIENCY}

Unspecific disturbances of rumen fermentation may cause depression of apparent thiamin synthesis in the rumen and depress thiamin concentration in blood (Gupta et al. 1976). Sheep fed on protein-free purified diets without supplemental B-vitamins may at times develop clinical symptoms of thiamin deficiency (Naga et al. 1975). Thus, there are indications that changing the type or increasing the amount of grain (Miller et al. $1986 \mathrm{~b}$; Muller et al. 1986), or changing to a maize-silage diet, may lead to a fall in rumen thiamin (Drozdowski, 1978; Candau \& Massengo, 1982). In other experiments it was suggested that an all-concentrate diet had led to suppression of rumen thiamin concentration in steers, as supplementation with thiamin resulted in significantly improved weight gains (Grigat \& Mathison, 1982). Thiamin supplements of $4-6 \mathrm{mg} / \mathrm{kg}$ feed have in fact been recommended for all-grain diets (Mathison, 1986). Such apparent thiamin deficiencies were not always accompanied by elevation of rumen thiaminase activity (Candau \& Massengo, 1982; Miller et al. $1983 \mathrm{~b}$ ), implying possible reductions in thiamin synthesis.

Accelerated destruction of thiamin in the rumen by increased microbial thiaminases, however, is probably the most important cause of thiamin deficiency (Edwin \& Jackman, 1982). Occurrence of unspecific symptoms, such as poor growth, were attributed to subclinical thiamin deficiency in a great number of grazing sheep ( $23 \%$ of the flock) in Southern Australia. The affected animals showed significantly higher thiaminase activities in faeces, associated with depression of general performance and weight gain. The severity of symptoms was significantly correlated with faecal thiaminase activity. With thiamin injections of $250 \mathrm{mg}$ /week general performance returned to normal (Thomas, 1986 a, b). In such cases rumen escape of supplemental thiamin may be reduced by elevated thiaminase activity in the rumen (Miller et al. $1986 \mathrm{~b}$ ). In general, oral or parenteral administration of thiamin improved the physical condition of animals with distinct thiamin deficiency, and biochemical indicators showed that there was an improvement in thiamin status (Pohlenz, 1975a).

There is, however, no reason to believe that intensive production management always leads to subclinical thiamin deficiency. In one large field trial with feedlot steers inclusion of supplemental thiamin in the diet or weekly intramuscular injections of thiamin had no significant effect on either weight gain or feed conversion, and very few animals showed biochemical signs of thiamin deficiency (Grigat \& Mathison, 1983a,b). There was also little or no improvement in shipping-stressed ruminating calves given a B-vitamin mixture containing thiamin (Zinn et al. 1987).

\section{Occurrence and clinical symptoms}

\section{CEREBROCORTICAL NECROSIS (CCN)}

CCN or polioencephalomalacia is a disease that has been reported in cattle, sheep, goats and wild ruminants under a variety of feeding conditions, i.e. grazing or intensive livestock production. It is spread almost all over the world and has been described in Europe, North and South America, Africa, Australia and New Zealand (Loew \& Dunlop, $1972 b$; Grant, 1976; Cryer, 1985; Federici \& Genovesi, 1985; Tanwar, 1987). The symptoms include anorexia, ataxia, convulsions, teeth grinding, opisthotonus, nystagmus, amaurosis, muscle twitching, recumbency and coma, and the outcome is often fatal. Such symptoms may also by induced in sheep by treatment with amprolium (Loew \& Dunlop, $1972 b$; Markson et al. 1974), a substance known to interfere with intestinal and cellular transport of thiamin (Rogers, 1982), and in such animals further signs of central nervous dysfunction are reduction of rapid eye movement sleep and abnormal slow wave spindle bursts in electrooculograms (Dunlop et al. 1980). The biochemical lesions responsible for the neurological 
symptoms of CCN are still unknown, but they do not seem to be brought about by uncomplicated thiamin deficiency. Mueller \& Asplund (1981) attempted to mimic clinical symptoms of CCN in sheep by feeding a thiamin-deficient purified liquid diet and parenteral infusion. The sheep developed biochemical and clinical signs of thiamin deficiency, but lacked neurological symptoms. Consumption of bracken fern elevates thiaminase in grazing animals (Chick et al. 1981), and wide areas of rough grazing in the temperate zones are densely covered with this weed (Dickie et al. 1979; Chick et al. 1981). However, the pathology of bracken poisoning differs markedly from that of $\mathrm{CCN}$ and symptoms do not respond to thiamin injections.

Thiamin and TPP concentrations in rumen, tissues (brain, liver) and blood of CCNaffected animals were depressed by $30-50$ and $50-80 \%$ respectively (Loew \& Dunlop, $1972 a$; Behrens \& Höller, 1977; Edwin \& Jackman, 1973, 1982).

Incidence rates of $\mathrm{CCN}$ may approach $10-50 \%$ with high mortality rates (McDonald, 1982; Bajmocy et al. 1986), or only a few animals of a group may be affected. Young animals under 1 year of age were more susceptible than adults. Feeding conditions which enhance the rate of VFA production in the rumen and which lead to lower rumen $\mathrm{pH}$ values appear to facilitate development of CCN. Adding straw to a high-grain diet prevented CCN in previously susceptible fattening calves (Hennig et al. 1976), while grinding and pelleting the fibrous components of a dried-grass-grain-sugar-beet diet induced $\mathrm{CCN}$ in a fattening cattle herd. Feeding conditions which lead to symptoms associated with subclinical thiamin deficiency or to $\mathrm{CCN}$ are apparently quite similar, and it seems beyond doubt that the symptoms of $\mathrm{CCN}$ are indicative of a state of severe thiamin deficiency, but whether they represent symptoms of uncomplicated vitamin $B_{1}$ deficiency seems unlikely. Fuller descriptions of pathogenesis and of further clinical and biochemical aspects have been given elsewhere (Evans, 1975; Edwin \& Jackman, 1982; Rammell \& Hill, 1986).

\section{Bacterial species associated with $C C N$}

Specific changes in the rumen microbial ecosystem are probably the primary factor leading to CCN. Acute $\mathrm{CCN}$ in ruminants was paralleled by distinct changes in composition and functional properties of the rumen microbial population (Haven et al. 1983). Characterization of distinct physicochemical and environmental factors in the rumen which are likely to induce such changes appears to be difficult. The relative importance of individual bacterial species which contribute to the changes in rumen metabolism and which eventually lead to increased thiaminase production are not yet defined. Increased breakdown of thiamin in the rumen is, however, usually associated with the presence of certain microbial species e.g. Bacteroides thiaminolyticus (Morgan \& Lawson, 1974; Thomas, 1986 b) and other Bacteroides species, Clostridium sporogenes, Megasphaera elsdenii and Streptococcus bovis (Edwin \& Jackman, 1982; Wilson et al. 1984). Bact. thiaminolyticus appears to be pathogenetically the most important species, since it was always found in rumen contents and faeces of CCN-affected animals; but it may also be present in the faeces of apparently healthy animals (Edwin \& Jackman, 1982). Identification of causative factors is complicated by the observation that the biochemical and enzymic properties of rumen thiaminase from animals which died from $\mathrm{CCN}$ differed from those of thiaminase isolated from pure cultures of Bact. thiaminolyticus or $\mathrm{Cl}$. sporogenes (Boyd \& Walton, 1977). These difficulties in identifying the causative factors in the rumen also led to the suggestion that rumen bacteria that normally exhibit no thiaminase activity may acquire the capability of producing thiaminase under certain intraruminal conditions. 


\section{Other dietary associations with $C C N$}

There are reports of cattle receiving forage-molasses-urea diets which showed clinical and some biochemical characteristics similar to those of $\mathrm{CCN}$. The disease, borrachera, could be induced by eliminating forage from such diets (Loew, 1975). There are, however, indications that the disorder is probably complicated by other metabolic disturbances. The central nervous symptoms encountered with this syndrome in Central America could not always be cured by administration of thiamin alone (Loew, 1975). On the other hand, recovery of animals showing typical symptoms of CCN after treatment with thiamin is prompt and often takes place within $1 \mathrm{~h}$ or less.

Among possible dietary inter-relations with minerals that have been investigated no experimental support could be provided for the idea that a deficiency of cobalt contributes to thiamin deficiency (Mann et al. 1983). Administration of $100 \mathrm{mg}$ thiamin/d to calves was shown to prevent, by a yet unknown mechanism, the development of symptoms of lead poisoning (Bratton et al. 1981 a). Thi גmin treatment of such disorders was shown to reduce significantly $\mathrm{Pb}$ concentration in blood and $\mathrm{Pb}$ deposition in liver and other tissues. The vitamin, however, did not alter the typical indicator of $\mathrm{Pb}$ intoxication, i.e. the decrease in porphobilinogen synthase (EC 4.2.1.24) in erythrocytes (Bratton et al. 1981 b).

It has been reported that the thiamin derivative thiamin tetrahydrofurfuryldisulphide (TFDS) lowered magnesium balance in sheep (Yano \& Kawashima, 1977) and rats (Itokawa et al. 1972), but $\mathrm{Mg}$ concentrations in the plasma of thiamin-deficient preruminant lambs were unaltered (Thornber et al. 1981).

\section{Treatment of $C C N$}

Clinical CCN can be effectively treated by oral or parenteral applications of thiamin; 200-500 mg for calves and sheep (Pohlenz, 1975b) and 1-2 g for cattle. Restoration of symptoms depends on how far central nervous lesions have already progressed. Oral treatments with thiamin or thiamin derivatives (thiaminpropyldisulphide (TPDS), TFDS) probably provide an advantage over parenteral administration, because oral treatments appear to exert a dual effect in that repletion of the B-vitamin deficiency of the host animal is achieved and inhibition of rumen thiaminase occurs, restoring its activity to normal (Suzuki \& Ooba, 1973; Thomas, 1986b). Support for the possible existence of strong primary-substrate inhibition of rumen thiaminase comes also from more recent observations which showed that purified thiaminase I activity could be depressed through 30 min incubation with either thiamin or TPDS (Thomas, 1986b).

\section{BIOCHEMICAL AND HISTOLOGICAL INDICATORS OF THIAMIN DEFICIENCY AND CCN}

Thiaminase activities in faeces of sheep with unspecific symptoms related to thiamin deficiency (e.g. poor weight gain) appear to be higher than those of normal animals (Thomas, 1986a). Probably the most specific and sensitive biochemical indicator for diagnosing thiamin deficiency is the increase in transketolase activity (EC 2.2.1.1) in erythrocytes on addition of TPP in vitro (Edwin \& Jackman, 1982). Measurement of this activity is widely used since it can be carried out in readily accessible material. An increase in the activity of this enzyme as demonstrated by an increase in the appearance rate of seduheptulose-7-phosphate of $30-50 \%$ compared to non-activated values is taken as indicative of subclinical thiamin deficiency (Clausen, 1977; Edwin \& Jackman, 1982; Edwin et al. 1976b); an increase of $80-100 \%$ is generally found during clinical CCN. If the rate of disappearance of ribose-5-phosphate is used as a measure of the TPP effect in vitro, 
values of $25 \%$ above normal may indicate a clinical state of deficiency and values of $15-25 \%$ point to subclinical states of thiamin deficiency.

Other biochemical lesions often encountered are lower blood and tissue levels of thiamin and accumulation of direct or indirect precursors of TPP-dependent enzymes, e.g. glucose, pyruvate, lactate, $\alpha$-ketoglutarate and other $\alpha$-ketoacids (Edwin \& Jackman, 1982). An absolute reduction of the erythrocyte transketolase activity could also be monitored during thiamin deficiency together with abnormally high increases of glucose, pyruvate, lactate or $\alpha$-ketoglutarate concentrations in plasma after an intravenous glucose load (Latham, 1967). In humans thiamin excretion in urine was found to correlate with a decrease in unactivated erythrocyte transketolase activity (Brubacher et al. 1972). Whether this also applies to ruminants is not known.

\section{NIACIN}

No clear-cut clinical signs of niacin deficiency have yet been reported in ruminants with a functioning rumen, but many reports have appeared suggesting a possible deficiency of niacin in high performing (growing, fattening and milking) ruminants under different feeding regimens (Byers, 1980; Dreosti, 1984). The suggestion is based on positive responses in general performance (weight gain, milk yield, efficiency of feed conversion and rate of synthesis of microbial protein in the rumen). However, no distinct biochemical features of latent or subclinical niacin deficiencies have been identified so far.

\section{FUNCTIONS}

In common feedstuffs the vitamin is present in two biologically active forms, as nicotinic acid and nicotinamide. Their common generic descriptor is 'niacin'. Especially in North America the term 'niacin' is also used as a synonym for nicotinic acid. In mammalian tissues tryptophan and quinolinic acid can also be converted into niacin (Shibata et al. 1986). Thus, the vitamin activity of a feed depends on its niacin, tryptophan, and quinolinic acid content and on the efficiency of conversion of tryptophan and quinolinic acid into nicotinamide. Total niacin activity of a feed, including that derived from conversion of precursors, is expressed as 'niacin equivalents' (Bender, 1980). In the present paper the term 'free niacin' is used to designate water-extractable nicotinic acid and nicotinamide. The term 'total niacin' will be used for free niacin plus nicotinamide incorporated into NAD and NADP. The abbreviations NAD and NADP are used for both the oxidized and the reduced forms of the coenzymes, but when distinction is needed between these forms they will be shown as $\mathrm{NAD}^{+}, \mathrm{NADH}$ and NADP ${ }^{+}, \mathrm{NADPH}$.

Bender (1980) and Hankes (1984) provide comprehensive discussions of comparative and nutritional aspects of niacin. Briefly both nicotinic acid and nicotinamide are incorporated into dinucleotide coenzymes NAD and NADP which serve as cosubstrates in many energyyielding oxidation-reduction processes. Nicotinamide dinucleotides are present in membranes and cytosol. The quantitatively most important role of the oxidized form of the two coenzymes (cosubstrates) involves their function as acceptors of reduction equivalents in reactions of the glycolytic pathway, the citric acid cycle and the degradation of fatty acids and proteins. The reduced forms, NADH and NADPH, are required for gluconeogenesis, for synthesis of free fatty acids, for provision of amino nitrogen through aspartate, for urea biosynthesis, and for the pentose phosphate pathway which also relies on the presence of thiamin. Reduction equivalents from NADH can be transferred to NADP by 'transhydrogenation' to form $\mathrm{NADPH}+\mathrm{H}^{+}$and NAD. Substrate oxidations take place in mitochondria, while the synthetic reactions are cytoplasmic processes.

Due to forestomach digestion an inherent limitation in the supply of glucose is present in ruminants. This has led to a limited ability of the ruminant liver, adipose tissue and 
mammary gland to use glucose carbon for lipogenesis by NADP-mediated reactions during periods of fattening or lactation (Ballard et al. 1969). NADPH, however, is of great importance for operation of the lipogenetic pathway which starts from acetyl-CoA.

\section{ASSAY OF NIACIN, NAD(P) AND ITS METABOLITES}

For evaluation of niacin supply and niacin status, concentrations of free niacin and of dinucleotide coenzymes in tissues and body fluids are of interest. This applies also to measurement of metabolites and end-products like $\mathbf{N}^{1}$-methyl-nicotinamide, nicotinuric acid and methyl-( 2 or 4)-pyridone-carboxamides which are excreted with urine. Turbidimetric methods using niacin-dependent bacteria are available for determination of free nicotinic acid, free nicotinamide or for total niacin (Vincke et al. 1984). These methods show sufficient sensitivity to be used with biological fluids, including particle-free rumen fluid where the niacin concentration is very low (Abdouli \& Schaefer, 1985).

The most common chemical assay is based on the rather non-specific reaction of substituted pyridines with cyanogen bromide which yields coloured or fluorescent compounds (König reaction) (Bender, 1980). More specific fluorimetric and highperformance liquid chromatographic (HPLC) methods for quantification of nicotinic acid, nicotinamide and niacin metabolites in serum, urine and ruminant digesta have been described (Clark et al. 1975; Kollenkirchen \& Harmeyer, 1989a, $b$; Shibata et al. 1987).

HPLC-based determination of these compounds in urine is still difficult because of substantial contamination with interfering substances. A method for quantification of niacin metabolites from urine using cation-exchange chromatography is, however, available (McCreanor \& Bender, 1986). Pertinent methods for determination of the oxidized and reduced forms of the coenzymes in blood and other tissues have been reviewed (Chytil \& McCormick, 1986).

\section{NIACIN ENTERING THE RUMEN FROM THE DIET AND ITS EFFECT ON NIACIN SUPPLY}

In ruminant feedstuffs, particularly in cereals, considerable proportions of total niacin may be bound by ester bonds to macromolecules (polysaccharides, polypeptides, glycopeptides; Hankes, 1984). It appears that bound niacin is generally unavailable for simple-stomached animals, but it may sometimes be made available by roasting. The extent to which bound niacin is available to ruminants and the effects of pelleting and roasting on this availability are unknown. Niacin concentration in rumen contents of sheep was positively related to the niacin content of feeds (Abdouli \& Schaefer, 1986a; Kollenkirchen, 1987). However, rumen bacterial NAD and NADP appeared to be unaffected by the dietary niacin content of the feed (Abdouli \& Schaefer, $1986 a$; J. Harmeyer, unpublished results), indicating that niacin synthesis by rumen microbes compensates for a deficiency of niacin in the feed, and that the niacin content in the rumen does not depend greatly on the dietary supply of niacin. This suggestion is also supported by measurements of apparent in vitro production of total niacin in strained rumen fluid of cattle; this progressively decreased when increasing amounts of nicotinic acid were added to the culture (Riddell et al. 1985). However, in another similar study using rumen fluid from milking cows, addition of niacin slightly increased microbial niacin synthesis but had no effect on microbial synthesis of NAD (Abdouli \& Schaefer, 1986a). This latter observation appears difficult to explain and probably needs further examination.

It is important to know how niacin supplements affect the niacin supply of the host animal under conditions of practical feeding. A dose of $250 \mathrm{mg}$ niacin administered through rumen fistulas of sheep raised niacin concentrations in rumen fluid for about $6 \mathrm{~h}$ (Fig. 3). When $400 \mathrm{mg}$ was given, concentrations were raised for $8 \mathrm{~h}$. The rate constant of 


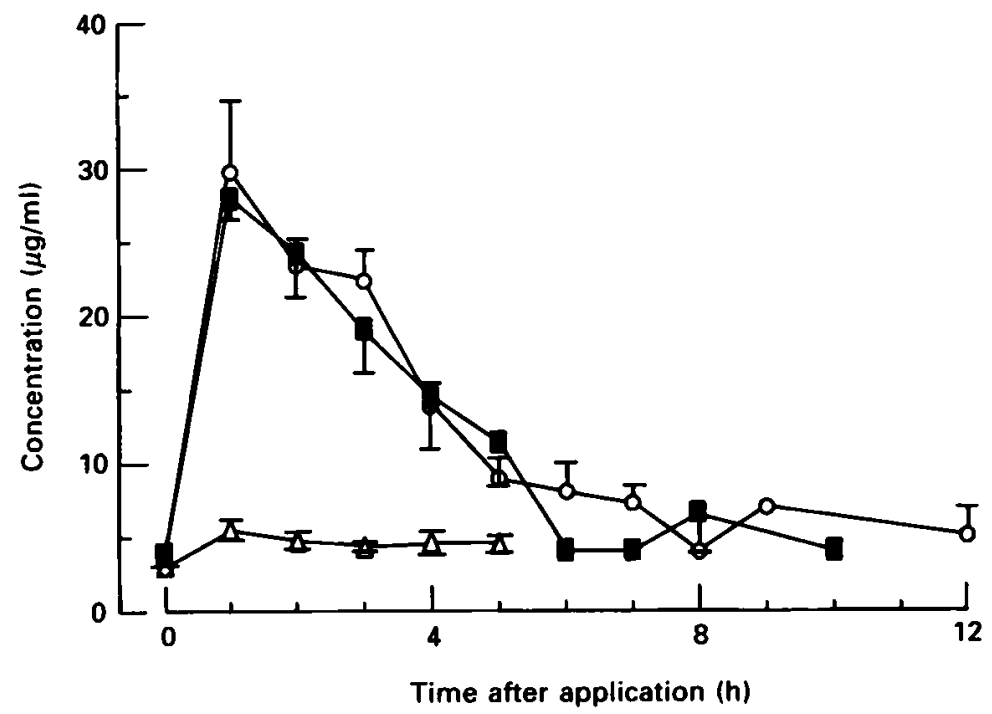

Fig. 3. The concentration of free nicotinic acid is elevated in strained rumen fluid of sheep for about 4-8 h after intraruminal administration of a single dose of either $250 \mathrm{mg}$ nicotinic acid or $250 \mathrm{mg}$ nicotinamide. The animals were fed on a concentrate sugar-beet pulp-chopped oat straw diet at 7,13 , 17 and $22 \mathrm{~h}$ (two animals, four experiments with nicotinic acid; two animals, two experiments with nicotinamide) (U. Kollenkirchen \& J. Harmeyer, unpublished results). ( $\mathrm{O}-\mathrm{O})$. Nicotinic acid; $\left(\square--\right.$ ) nicotinamide; $\left(\triangle^{-}-\triangle\right)$, control. Points are means with their standard errors represented by vertical bars.

disappearance was about $50 \% / \mathrm{h}$. The niacin supplement also led to an increase in niacin concentrations associated with the microbial fraction. It was estimated that about 20 and $30 \%$ of rumen doses of 250 and $400 \mathrm{mg}$ niacin respectively entered the duodenum, while the remaining proportion was degraded in the rumen (Kollenkirchen \& Harmeyer, 1986; J. Harmeyer, unpublished results). In experiments in steers a single $200 \mathrm{mg}$ supplement of nicotinic acid into the rumen resulted in non-significant change in daily duodenal flow of nicotinic acid, whereas adminstration of $2 \mathrm{~g} / \mathrm{d}$ increased duodenal flow by $6.2 \%$ of the administered dose (Zinn et al. 1987). In other experiments with fattening cattle a daily supplement of $6 \mathrm{~g}$ nicotinic acid, given in three equal portions of $2 \mathrm{~g}$, increased total niacin concentration in duodenal digesta from 5.5 to $8.5 \mu \mathrm{g} / \mathrm{ml}$ (Riddell et al. 1985).

It appears from these experiments that rumen escape of supplementary niacin as a percentage of dose increases with the dose. It may be zero at small doses and may amount to $30 \%$ at higher doses. No absorption of niacin from the rumen was found in experiments using washed rumens of sheep (J. Harmeyer, unpublished observations).

There appears to be no difference in the supply of niacin to the host animal when the vitamin is given as either the acid or as the amide. In our studies with fistulated sheep ( $U$. Kollenkirchen \& J. Harmeyer, unpublished results) it was shown that nicotinamide administered into the rumen was almost instantly hydrolysed to nicotinic acid and ammonia, probably due to the presence of microbial deamidases (Warner, 1964) which have also been found in the rat intestines (McCreanor \& Bender, 1986). There is also evidence that most tissues can utilize both nicotinic acid and nicotinamide for synthesis of NAD and NADP (Bender \& Bender, 1986).

\section{SYNTHESIS OF NIACIN IN THE RUMEN}

Earlier studies with sheep and cattle suggested that microbial synthesis of niacin is adequate under conventional feeding conditions to meet the niacin requirements of the host animal 
(Barnett \& Reid, 1961; Porter, 1961). However, Naga et al. (1975) found that in sheep receiving purified protein-free, urea diets for about two years, intermittent symptoms of niacin deficiency occurred. Many bacterial species capable of synthesizing niacin have been identified in rumen contents e.g. Bacterium ruminicola ssp. brevis, Bacteroides succinogenes, Ruminococcus flavefaciens, Lachnospira multiparus, Streptococcus bovis, Butyrivibrio (Menke, 1973). There is evidence from in vitro and in vivo studies that apparent synthesis of total niacin in the rumen and niacin flow to the duodenum are positively related to microbial synthesis of protein (Shields et al. 1983; Zinn et al. 1987). The absolute amounts of niacin available to the ruminant per unit microbial dry matter which enters the duodenum may vary, however, with changes in composition of the microbial population and may at times under unconventional feeding conditions be too low to meet the animal's requirements.

It appears important to know how niacin is distributed between the various phases of rumen contents and in which fraction it is predominantly present. From measurements in the rumen contents of dairy cows (Abdouli \& Schaefer, 1986a) and sheep (U. Kollenkirchen \& J. Harmeyer, unpublished results) it was found that, in contrast to thiamin, approximately $90 \%$ of free niacin was associated with the microbial fraction. Particle-free rumen fluid contained only 3-5\% and the remaining proportion was associated with food particles. Nicotinamide in its free form could not be detected in particle-free rumen fluid of sheep. Besides the free niacin, however, an almost equal quantity was present in the NAD and NADP coenzymes (Abdouli \& Schaefer, 1986a; U. Kollenkirchen \& J. Harmeyer, unpublished results). About $25-35 \%$ of the coenzyme was found in particle-free rumen fluid (Abdouli \& Schaefer, 1986a) and in batch cultures about $80-90 \%$ of the coenzymes were NAD and 10-20\% were NADP. Less than 10\% of the dinucleotides were in the reduced form (Shields et al. 1983). These results show that the niacin concentration in rumen effluent is probably higher than that of mixed rumen contents, and when estimating duodenal flow of niacin and evaluating the niacin supply of the host animal, both free niacin and niacin incorporated into the coenzymes of rumen effluent have to be taken into account.

It should be noted that when feeding high-quality high-energy diets, as required for highproducing dairy cows, the proportion of dietary protein which escapes the rumen undegraded may be increased (Van Soest, 1982; Rohr et al. 1986). Consequently, the proportion of microbial protein which contributes to total protein entering the duodenum may be lower than when conventional diets are given. Such changes in rumen digestion inevitably lead to concomitant changes in composition of duodenal digesta and may result in reductions of the duodenal supply of microbial niacin. This diminished supply would parallel an increased demand due to the high level of production.

Food additives which are known to influence microbial activity in the rumen are also likely to affect the apparent synthesis of niacin. A $22 \mathrm{mg}$ monensin supplement $/ \mathrm{kg}$, for example, to a maize grain-lucerne (Medicago sativa)-meal diet depressed duodenal flow of niacin in steers (Miller et al. 1986a). Depression of the duodenal flow of niacin with chlortetracycline supplementation has also been reported (Miller et al. 1986a) and this tended to increase with the amount of dose administered.

It appears that manipulations of rumen fermentation aimed at increasing energy utilization in the rumen are likely to reduce net synthesis of niacin and perhaps of other Bvitamins, provided such manipulations also depress apparent microbial growth in the rumen. 


\section{ABSORPTION FROM THE SMALL INTESTINE AND SUBSEQUENT METABOLISM}

It has been found that $60-80 \%$ of the free niacin that enters the duodenum of steers (Miller et $a l .1986 a, b$ ) or sheep (U. Kollenkirchen \& J. Harmeyer, unpublished results) is absorbed from the small intestine. The mechanism of niacin absorption from the small intestine has not yet been fully resolved. Samples of duodenal digesta from sheep contained free nicotinic acid, NAD and NADP as well as free nicotinamide (U. Kollenkirchen \& J. Harmeyer, unpublished results). The latter was probably formed by the action of bacterial or mammalian nucleotidases (Pike \& Brown, 1975). In rats formation of nicotinamide from brush-border-associated dinucleotides has also been reported (Gross \& Henderson, 1983). Thus, it appears that the ruminant host has access to both nicotinic acid and nicotinamide to meet the specific requirements of individual organs (Giesecke, 1983). The mechanisms of absorption have not been studied in the ruminant intestine, but are likely to be similar to those in non-ruminants where both active (sodium-dependent) and passive mechanisms have been described (Schuette \& Rose, 1983; Elbert et al. 1986).

Due to the possible intermediary synthesis of niacin from tryptophan via kynurenine and quinolinic acid, niacin is, in the strict sense, not a true vitamin (Bender, 1980). Efficiency of synthesis from tryptophan was estimated to be about one part niacin from sixty parts dietary tryptophan but the efficiency may be markedly influenced by dietary and hormonal factors (Bender et al. 1982; Bender \& Bender, 1986). However, it appears unlikely that in ruminants significant biosynthesis of niacin takes place under conditions in which niacin deficiencies are likely to occur, i.e. during intensive production. Under such conditions no extra tryptophan appears to be available for niacin biosynthesis.

It has been reported that the biosynthesis of niacin and NAD is depressed by ketone bodies (Yamada et al. 1983) but stimulated by cortisol and other glucocorticoids (Cox \& Mathias, 1969). These observations point to the possibility that the curative effect of glucocorticoid therapy in clinical bovine and ovine ketosis may be mediated, at least partly, through provision of sufficient NAD for restoration of the impaired energy-yielding pathways characteristic of bovine ketosis.

\section{EFFECTS OF SUPPLEMENTAL NIACIN}

In recent years niacin has been used widely to supplement diets for high-performing ruminants (Zweiacker, 1982; Schultz, 1983). The positive effects on performance characteristics, which were seen in some of these trials, provide no information as to whether such effects result from influences of niacin on the rumen or on systemic functions or on both. Earlier work had indicated that some rumen bacteria require niacin for growth (Allison, 1969). More recent work, mainly in vitro, investigated the effect of niacin on rumen functions such as microbial growth, VFA production, assimilation of ammonia, net protein synthesis or feed conversion. These studies have yielded inconsistent results (Table 1). Probably the main conclusion that can be drawn is that the conditions needed for niacin to have a beneficial effect cannot yet be defined with any degree of certainty. This may have to do with the difficulty of discerning effects on rumen function of only minor magnitude. The use of rumen fluid in in vitro studies to predict what may happen in quantitative terms in the rumen is also limited by variables which are difficult to control. Rumen samples are likely to vary in microbial composition and are in any event often not representative of the varying total rumen population. Diurnal variation in the concentration of the rumen protozoa which are probably niacin consumers (Abdouli et al. 1983) constitutes an additional variable in experiments of this kind (Dennis et al. 1982). It is also advisable when in vitro effects of niacin or other micronutrients on microbial fermentation are to be studied 
Table 1. Effect of niacin supplementation on microbial fermentation in the rumen

\begin{tabular}{|c|c|c|c|}
\hline & $\begin{array}{l}\text { Effect on } \\
\text { microbial } \\
\text { growth }\end{array}$ & Remarks & References \\
\hline \multicolumn{4}{|c|}{ (a) In vitro studies* } \\
\hline $\begin{array}{l}\text { Substrate: } \\
\text { Soluble carbohydrate }\end{array}$ & None & $\begin{array}{l}\text { Substrate con- } \\
\text { centration } \\
\text { probably } \\
\text { inadequate }\end{array}$ & Abdouli \& Schaefer (1986b) \\
\hline $\begin{array}{l}\text { Soluble carbohydrate } \\
\text { Insoluble carbohydrate }\end{array}$ & $\begin{array}{l}\text { None } \\
\text { Increase } \\
\quad P<0.05\end{array}$ & $\begin{array}{l}\text { Semi- } \\
\text { continuous culture }\end{array}$ & $\begin{array}{l}\text { Abdouli \& Schaefer (1986a) } \\
\text { Shields et al. (1983) }\end{array}$ \\
\hline $\begin{array}{l}\text { Maize + hay + starch } \\
\text { urea }\end{array}$ & Increase $†$ & $\begin{array}{l}\text { Increase in } \\
\text { gas production }\end{array}$ & Bartley et al. (1979) \\
\hline $\begin{array}{l}\text { Maize or hay, or both, } \\
\text { + urea }\end{array}$ & $\begin{array}{l}\text { Increase } \\
P<0.01\end{array}$ & & Riddell et al. (1980) \\
\hline $\begin{array}{l}\text { Sorghum + grain + urea } \\
\text { Maize + hay }\end{array}$ & $\begin{array}{l}\text { Increase } \dagger \\
\text { None }\end{array}$ & $\begin{array}{l}\text { Continuous } \\
\text { culture }\end{array}$ & $\begin{array}{l}\text { Riddell et al. (1980) } \\
\text { Schaetzel \& Johnson (1981) }\end{array}$ \\
\hline $\begin{array}{l}\text { Cellulose } / \text { purified } \\
\text { roughage + glucose }\end{array}$ & Increase $\dagger$ & $\begin{array}{l}\text { Increase be- } \\
\text { tween niacin- } \\
\text { supplemented donor } \\
\text { animals and controls, } \\
\text { no niacin added in vitro }\end{array}$ & Schussler et al. (1978) \\
\hline \multicolumn{4}{|c|}{ (b) In vivo studies with young steers } \\
\hline $\begin{array}{l}\text { Feed: } \\
\text { Soya-bean meal + straw }\end{array}$ & None & $\begin{array}{l}\text { No change in } \\
\text { rumen function } \\
\text { or composition }\end{array}$ & Arambel et al. (1986) \\
\hline Maize + hay + molasses & None & & Zinn et al. (1987) \\
\hline
\end{tabular}

* In vitro experiments were batch cultures for 6-24 h, unless otherwise stated.

$\dagger$ Statistical significance doubtful.

to choose experimental conditions which allow maximal growth of microbes, i.e. to add excess of substrate. In the presence of suboptimal amounts of substrate or other growth factors microbial metabolic functions may already be limited by these deficiencies which could then mask the effects to be tested. It appears that the culture media of some of the in vitro studies used to test effects of niacin did not always contain sufficient quantities of substrate to allow maximal growth (Abdouli \& Schaefer, $1986 a, b$; Shields et al. 1983).

Supplementation of ruminant feeds with niacin has been reported to increase milk production under certain dietary conditions (Table 2). But as indicated previously early lactation of high-performing milking cows probably constitutes a condition for development of marginal inadequacies of niacin. Some of the feeding trials shown in Table 2 have indeed shown increases in milk production or in milk constituents (between 0.5 and $5 \%$ ) in association with niacin supplements. However, effects in many of these trials were not significant, while in other experiments no or slightly negative effects were seen. The vagaries associated with the outcome of such feeding experiments probably result also, at least partly, from difficulties in accurately defining the nutritional and environmental conditions that may ultimately lead to subclinical niacin deficiency. Undoubtedly, such deficiencies do not always occur in cows that produce milk at a high level. Finally, it should be mentioned that supplemental niacin tended to increase inorganic phosphate in plasma 
Table 2. Effect of niacin supplementation on yield and composition of milk in early lactation $\dagger$

\begin{tabular}{|c|c|c|c|c|}
\hline Feed & $\begin{array}{l}\text { Effect on } \\
\text { milk yield }\end{array}$ & $\begin{array}{l}\text { Effect on } \\
\text { milk fat }\end{array}$ & Remarks & Reference \\
\hline $\begin{array}{l}\text { Concentrate }+ \text { brewer's } \\
\text { grains }+ \text { sugar- } \\
\text { beet pulp }\end{array}$ & None & None & & $\begin{array}{l}\text { Reid \& Treacher } \\
\text { (1983) }\end{array}$ \\
\hline \multirow[t]{2}{*}{$\begin{array}{l}\text { Maize silage }+ \text { beets } \\
+ \text { hay }+ \text { concentrate }\end{array}$} & None & Increase (NS) & & $\begin{array}{l}\text { Sipöcz \& Schmidt } \\
\text { (1985) }\end{array}$ \\
\hline & Increase (NS) & Increase (NS) & & Sipöcz \& Schmidt (1985) \\
\hline $\begin{array}{l}\text { Not specified: } \\
\text { without urea }\end{array}$ & Increase (NS) & lncrease (NS) & & Schwab (1983) \\
\hline With urea & Decrease (NS) & Increase (NS) & & Schwab (1983) \\
\hline Concentrate + forage & None & None & $\begin{array}{l}\text { More milk in high- } \\
\text { yielding first } \\
\text { lactation cows* }\end{array}$ & Jaster $e$ l al. $([983 a)$ \\
\hline $\begin{array}{l}\text { Maize }+ \text { silage }+ \\
\text { concentrate/pasture }\end{array}$ & Increase* & None & & Muller et al. (1986) \\
\hline $\begin{array}{l}\text { Silage + concentrate } \\
\text { + hay + cottonseed }\end{array}$ & None & Increase* & $\begin{array}{l}\text { Response differed } \\
\text { with diet }\end{array}$ & Horner et al. (1986) \\
\hline $\begin{array}{l}\text { Maize + silage + } \\
\text { hay + soya-bean meal }\end{array}$ & Increase (NS) & & & Jaster et al. $(1983 b)$ \\
\hline $\begin{array}{l}\text { Maize + soya-bean meal } \\
\text { or urea + molasses }\end{array}$ & None & None & & Kung et al. (1980) \\
\hline $\begin{array}{l}\text { Silage + beets }+ \\
\text { concentrate + straw }\end{array}$ & Increase (NS) & None & $\begin{array}{l}\text { Increase in yield } \\
\text { was higher in } \\
\text { first lactation } \\
\text { cows }\end{array}$ & $\begin{array}{l}\text { Grosse-Holz \& } \\
\text { Harmeyer (1988) }\end{array}$ \\
\hline $\begin{array}{l}\text { Silage }+ \text { hay }+ \\
\text { concentrate }\end{array}$ & None & Increase** & $\begin{array}{l}\text { Increase in } \\
\text { first lactation } \\
\text { cows }\end{array}$ & $\begin{array}{l}\text { Harmeyer \& } \\
\text { Grabe (1981) }\end{array}$ \\
\hline Grain + hay & Increase (NS) & None & & Riddell et al. (1981) \\
\hline $\begin{array}{l}\text { Sorghum grain }+ \\
\text { soya-bean meal }+ \\
\text { urea-treated starch }\end{array}$ & Decrease* & None & $\begin{array}{l}\text { Niacin supple- } \\
\text { mentation } 5 \text { weeks } \\
\text { after peak lactation }\end{array}$ & Riddell et al. (198I) \\
\hline $\begin{array}{l}\text { Sorhum grain + maize, } \\
\text { or soya-bean meal, or both } \\
\text { + urea-treated starch }\end{array}$ & $\begin{array}{l}\text { Increase (NS) } \\
\text { Decrease (NS) }\end{array}$ & $\begin{array}{l}\text { None } \\
\text { None }\end{array}$ & $\begin{array}{l}\text { With soya-bean meal } \\
\text { With starch urea }\end{array}$ & Riddell et al. (1981) \\
\hline $\begin{array}{l}\text { Maize + grain + } \\
\text { soya-bean meal + lin- } \\
\text { seed cake + bran }\end{array}$ & Increase (NS) & & & Bergonzini et al. (1977) \\
\hline Silage + concentrate & Increase (NS) & Increase (NS) & & Günther (1987) \\
\hline
\end{tabular}

NS, not significant or statistical significance doubtful.

* $P<0.05, * * P<0.01$.

+ Niacin supplements were 5-12 g/d, unless otherwise stated.

and to decrease total serum calcium (Byers, 1982; Dufva et al. 1984). Information is lacking as to whether this effect is of clinical relevance.

Available information suggests that responses in growing and fattening ruminants to niacin supplements are more consistent than in milking cows during early lactation. Consistent positive responses to niacin supplements have been found, mainly in the United States, with fattening beef cattle (Zweiacker, 1982; Robinson, 1986) and sheep (Miller et al. $1983 d$; Shields et al. 1983) when the effect is expressed as an increase in weight gain or in feed efficiency (about $0.5-9 \%$ ), or both. It is, however of interest that the positive responses in weight gain of supplemented steers was often matched by catch-up growth of the control 
animals during the final fattening period. In fact, Byers (1982) reported that after about 18 weeks niacin-supplemented and control groups of steers had reached about the same weight. It is tempting to suggest that the rations in some of these studies may also have contained other food additives, for example monensin, which could have inhibited microbial growth and thereby depressed apparent niacin synthesis in the rumen. Adaptation of calves (Byers, 1979) and lambs to maize-silage-containing diets was also improved by niacin supplements.

\section{PHARMACOLOGICAL AND TOXIC EFFECTS}

Nicotinic acid, but not nicotinamide, when administered in pharmacological amounts influences a number of metabolic and circulatory functions which are different from those associated with its enzyme function (Gey \& Carlson, 1970). Among these effects its antilipidaemic action (Lafrance et al. 1979; Gustafsson \& Kiessling, 1982) has been thought to be of relevance for the treatment of bovine ketosis (Schultz, 1971; Dufva et al. 1983; Jaster et al. 1983a). This idea was supported by the observation that total concentrations of nicotinamide dinucleotides in mammary gland biopsies were significantly lower in cows with spontaneous clinical ketosis than in normal control cows (Kronfeld \& Raggi, 1964). Other observations reinforcing the concept of using nicotinic acid as an anti-ketotic drug were that nicotinic acid in pharmacological amounts lowered non-esterified fatty acid and cholesterol concentrations in plasma and elevated plasma glucose concentrations in ruminants as well as in non-ruminants (Latham, 1967; Décombaz \& Roux, 1982). In high amounts it also depressed ketogenesis in isolated rat hepatocytes by a mechanism independent of cAMP (Yeh, 1979), and increased glycogenolysis and the hepatic output and utilization of glucose (Décombaz \& Roux, 1982). The anti-lipidaemic action of nicotinic acid, however, is thought to be mediated, at least in part, by inhibition of the synthesis of cAMP which is induced by lipolytic hormones (Yeh, 1976). Potential usefulness of prophylactic or therapeutic treatment of bovine ketosis with nicotinic acid, however, appears to be still unclear. In one experiment niacin lowered mean ketone body concentrations in plasma but had no influence on the incidence of clinical ketosis compared to the control group (Harmeyer \& Grabe, 1981). In another study, using $12 \mathrm{~g}$ nicotinic acid/d as a prophylactic treatment, the vitamin was ineffective in elevating plasma glucose concentrations or in depressing $\beta$-hydroxybutyrate or free fatty acid concentrations in plasma (Ruegsegger \& Schultz, 1986). There was also no effect on daily milk yield. Moreover, the reasoning behind the use of nicotinic acid as an anti-ketotic drug is apparently not entirely conclusive in view of the fact that the vitamin also lowers the concentration of triglycerides in plasma (Zöllner, 1971). Secretion of triglycerides and lipoproteins by the liver is, however, already low in ketotic cows. In fact, the limited ability of the ruminant liver to secrete sufficient amounts of triglycerides is considered to be one of the causative factors in the development of bovine ketosis (Laarsveld, 1983). There is also the problem that early pharmacological effects on lipid metabolism may be followed by a rebound phase during which many of them are temporarily reversed.

Although some toxic effects of nicotinic acid have been observed in humans and dogs (Alhadeff et al. 1984; Chen et al. 1984), such effects have not been reported in ruminants.

\section{INDICATORS OF NIACIN DEFICIENCY}

It was shown with dairy cows that prepartum concentrations of total niacin in erythrocytes fell significantly after parturition (Dufva et al. 1983) and positively responded to dietary supplements of niacin (Jaster et al. 1983 a), suggesting the possibility that this value may reflect changes in niacin status. However, information is lacking as to what values of erythrocyte or plasma niacin concentrations are indicative of niacin deficiency. 
Nicotinamide dinucleotide concentrations in plasma have been shown to reflect niacin intake in humans (Shibata, 1987), while Bender et al. (1982) considered that liver and other tissue concentrations of NAD and NADP may be as sensitive indicators of niacin status in rats. The suitability of these measurements for assessing niacin status in ruminants has not been tested.

Since niacin is metabolized to form various compounds which are excreted in the urine (e.g. nicotinuric acid, $\mathrm{N}^{1}$-methyl nicotinamide, methyl-(2 or 4)-pyridone-carboxamide) these metabolites may serve to diagnose niacin deficiency (Stanulovic \& Chaykin, 1971; Bender, 1980). $\mathbf{N}^{1}$-methyl-nicotinamide appears to be the principal niacin metabolite in urine in non-ruminant species at physiological and moderately elevated niacin intakes (Bender, 1980), and urine excretion of this compound has also been used to assess the niacin status of dairy cows (Bergonzini et al. 1977). But again, values indicative of niacin deficiency have not been established. Estimation of the $\mathrm{N}^{1}$-methyl-2-pyridone-5carboxamide: $\mathrm{N}^{1}$-methyl-nicotinamide ratio in the urine of non-ruminants has been proposed as a means of assessing subclinical niacin depletion (Säuberlich, 1981). The possibility that this ratio may also serve as an indicator when assessing the niacin status of ruminants has, however, not yet been examined. In general, similarities in the intermediary metabolism of niacin in ruminants and non-ruminants would justify testing indicators proved valid for non-ruminant animals for ruminants. Development of such indicators is essential to test whether performance responses to niacin supplements are, in fact, related to the niacin status.

\section{SUMMARY AND CONCLUSIONS}

Of the rumen thiamin $90 \%$ is present in the particle-free rumen fluid and is readily accessible to thiamin-degrading enzymes. Net synthesis of thiamin in the rumen occurs because microbial synthesis generally exceeds microbial destruction, and it is usually sufficient to meet the animals' requirements. Under certain feeding conditions net synthesis of thiamin in the rumen may be reduced, due either to diminished microbial synthesis or to enhanced enzymic breakdown. Thiaminase activity in the rumen responsible for thiamin destruction is usually very small but may considerably increase under certain conditions. These conditions may occur, for example, when diets are given which are high in concentrate, molasses or sulphates, or which contain thiaminase or anti-thiamins. Conditions which stimulate rumen microbial thiaminase activity by, for example, leading to a marked fall in rumen $\mathrm{pH}$ or a lowering of the redox potential may also lead to thiamin deficiency. Rumen fluid from normal animals appears to inhibit thiaminase activity, and the physicochemical factors which lead to increased production of thiaminase in the rumen have not yet been defined. Poor growth and diminished general performance in grazing sheep which promptly responded to thiamin supplements appeared to be associated with subclinical thiamin deficiency. $\mathrm{CCN}$ is a widespread disease with neurological symptoms of thiamin deficiency and can sometimes be treated effectively by feeding supplementary thiamin. It is possible, however, that this disease is not due simply to thiamin deficiency. Measurement of increases in transketolase activity in erythrocytes on addition of TPP constitutes a specific and sensitive indicator for diagnosing marginal and clinical states of thiamin deficiency.

Net synthesis of niacin in the rumen appears to be sufficient to meet the animals' requirements under many different feeding conditions. About $80-90 \%$ of rumen niacin is present in the microbial fraction with which it enters the small intestine. Almost $50 \%$ of total niacin in the rumen is incorporated into coenzymes. This fraction appears to be largely unaffected by changes in niacin intake with the feed, indicating that microbial synthesis 
compensates for changes in niacin intake with the feed. There is evidence that in high performing animals-high lactating cows for example-niacin supplements may have beneficial effects on production, but these conditions have not yet been clearly defined. The same is true for rapidly growing animals with the possibility that subclinical deficiencies may more likely develop when certain feed additives that interfere with microbial activity are used. Evidence for these assumptions is based almost entirely on reported responses and the experiments are less convincing with high lactating cows than with fattening cattle and sheep. It appears from the recommended doses of niacin supplements that about $10-30 \%$ becomes available to host animals with an increased availability, as percentage of dose, at higher levels of dosage. Future work should attempt to identify more reliable biochemical indicators of marginal niacin deficiency that can be used in ruminants as well as in nonruminants.

\section{REFERENCES}

Abdouli, H. \& Schaefer, D. M. (1985). Niacin saturation constants for Lactobacillus plantarum and Treponema bryantii. Journal of Dairy Science 68, 2372-2376.

Abdouli, H. \& Schaefer, D. M. (1986a). Effects of two dietary niacin concentrations on ruminal fiuid free niacin concentration, and of supplemental niacin and source of inoculum on in vitro microbial growth, fermentative activity and nicotinamide adenine dinucleotide pool size. Journal of Animal Science 62, $254-262$.

Abdouli, H. \& Schaefer, D. M. (1986 b). Impact of niacin and length of incubation on protein synthesis, soluble to total protein ratio and fermentative activity of ruminal microorganisms. Journal of Dairy Science 62 , $244-253$.

Abdouli, H., Schäfer, D. M. \& Pope, A. L. (1983). Effects of niacin supplementation on the rumen microbial population. Journal of Animal Science 57, 415 Abstr.

Alhadeff, L., Gualteri, C. T. \& Lipton, M. (1984). Toxic effects of water-soluble vitamins. Nutrition Revien's 42. 33-40.

Allison, M. J. (1969). Biosynthesis of amino acids by ruminal microorganisms. Journal of Animal Science 29. 797-807.

Arambel, M. J., Bartley, E. E., Dennis, S. M., Riddell, D. O., Camac, J. L., Higginbotham, J. F., Simons, G. G. \& Dayton, A. D. (1986). Effect of toasted soybean meal with or without niacin on rumen fermentation, passage rate of duodenal digesta and digestibility of nutrients. Nutrition Reports International 34, $1011-1020$.

Bajmocy, E., Fazekas, B. \& Tanyi, J. (1986). Occurrence of cerebrocortical necrosis (CCN) of calves in Hungary (Hungarian) Magyar Allatorvosok Lapja 41, 643-646 Abstr.

Ballard, F. J., Hanson, R. W. \& Kronfeld, D. S. (1969). Gluconeogenesis and lipogenesis in tissue from ruminant and nonruminant animals. Federation Proceedings 28, 218-231.

Barnett. A. J. G. \& Reid, R. L. (1961). Reactions in the Rumen, pp. 208-212. London: Edward Arnold.

Barschdorf, D. (1985). Gastrointestinale Bilanz von Thiamin (Vit. B B $_{1}$ bei Schafen mit diätetische bedingter Phosphordepletion (Gastrointestinal balance of thiamin (Vit. $B_{1}$ ) in phosphorus depleted sheep). Thesis med. vet., Veterinary School Hannover.

Bartley, E. E., Herod, E. L., Bechtle, R. M., Sapienza, D. A. \& Brent, B. E. (1979). Effect of monensin or lasalocid, with and without niacin or amicloral, on rumen fermentation and feed efficiency. Journal of Animal Science 49, 1066-1075.

Behrens, H. \& Höller, H. (1977). Thiamingehalte in Lebern und Gehirnen von Schafen mit Cerebralnekrose, Listeriose und anderen Erkrankungen (Thiamin contents of liver and brain of sheep with cerebrocortical necrosis, listeriosis and other diseases). Deutsche Tierärztliche Wochenschrift 84, 305-307.

Bender, D. A. (1980). Niacin. In Vitamins in Medicine, pp. 315-347 [B. N. Barker and D. A. Bender, editors] London: William Heinemann Medical Books Ltd.

Bender, D. A. \& Bender, A. E. (1986). Niacin and tryptophan metabolism: the biochemical basis of niacin requirements and recommendations. Nutrition Abstracts and Reviews 56, 695-719.

Bender, D. A., Magboul, B. I. \& Wynick, D. (1982). Probable mechanisms of regulation of the utilization of dietary tryptophan, nicotinamide and nicotinic acid as precursors of nicotinamide nucleotides in the rat. British Journal of Nutrition 48, 119-127.

Bergonzini, E., Fabri, R., Martillotti, F., Piva, G. \& Amerio, M. (1977). Influenza della nicotinamide nell'alimentazione delle vacche da latte. (Effects of feeding nicotinamide to dairy cows.) Annali del Istitufo Sperimentale per la Zootecnia 10, 57-72.

Black, A. L., Kleiber, M., Butterworth, E. M., Brubacher, G. B. \& Kaneko, J. J. (1957). The pentose phosphate cycle as a pathway for glucose metabolism in intact lactating dairy cows. Journal of Biological Chemistry 227, 537-550.

Bogin, E., Soback, S. \& Immelman, A. (1985). Transketolase activity in the blood of cattle and sheep in relation to thiamine deficiency. Zentralblatt für Veterinärmedizin A 32, 135-139. 
Boyd, J. B. \& Walton, J. R. (1977). Cerebrocortical necrosis in ruminants; an attempt to identify the source of thiaminase in afflicted animals. Journal of Comparative Pathology 87, 581-589.

Bratton, G. R., Zmudzki, J., Bell, M. C. \& Warnock, L. G. (1981a). Thiamin effects on lead intoxication and deposition of lead in tissues: therapeutic potential. Toxicology and Applied Pharmacology 59, $164-172$.

Bratton, G. R., Zmudzki, J., Kincaid, N. \& Joyce, J. (1981b). Thiamin as treatment of lead poisoning in ruminants. Modern Veterinary Practice $62,441-446$.

Brent, B. E. \& Bartley, E. E. (1984). Thiamin and niacin in the rumen. Journal of Animal Science 59, 813-822.

Breves, G., Brandt, M., Höller, H. \& Rohr, K. (1981). Flow of thiamin in the duodenum in dairy cows fed different rations. Journal of Agricultural Science 96, 587-591.

Breves, G., Höller, H., Harmeyer, J. \& Martens, H. (1980). Thiamin balance in the gastrointestinal tract of sheep. Journal of Animal Science 51, 1177-1181.

Breves, G., Schmitt, R. \& Höller, H. (1982). Thiamin compartment models in healthy sheep. International Journal for Vitamin and Nutrition Research 52, 3-8.

Brubacher, G., Haenel, A. \& Ritzel, G. (1972). Transketolaseaktivität, Thiaminausscheidung und Blutthiamingehalt beim Menschen zur Beurteilung der Vitamin-B -Versorgung. (Transketolase activity, excretion of thiamin and content of thiamin in blood in man as an indicator of thiamin supply.) International Journal for Vitamin and Nutrition Research 42, 190-195.

Byers, F. M. (1979). Niacin and beef cattle performance. B vitamin enhances energy efficiency and adaptation to urea. Animal Nutrition and Health 34 (8), 20-22.

Byers, F. M. (1980). Niacin for ruminants - a review. Feed Management 31 (7), 24-30.

Byers, F. M. (1982). Interactions between micronutrients and B-vitamins in ruminants. Nuevos Conceptos Sobre Vituminas $Y$ Aditivos Para Ruminantes, Proceedings of the Micronutrient Symposium pp. 1-7. Mexico City: Universidad Nacional Autonoma de Mexico.

Candau, M. \& Kone, L. (1980). In vitro effect of thiamin on rumen microbial metabolism. Reproduction, Nutrition, Développement 20, $1695-1699$.

Candau, M. \& Massengo, J. (1982). Evidence of a thiamine deficiency in sheep fed maize silage. Annales de Recherches Vétérinaires 13, 329-340.

Chen, K. K., Rose, E. L. \& Robbins, E. B. (1984). Toxicity of nicotinic acid. Nutrition Review's 42, 52-54.

Chick, B. F.. Carroll, S. N., Kennedy, C. \& McCleary, B. V. (1981). Some biochemical features of an outbreak of polioencephalomalacia in sheep. Australian Veterinary Journal 57, 251-252.

Chytil, F. \& McCormick, D. B. (1986). Nicotinic acid: analogs and coenzymes. Methods in Enzymology 122, 147-184.

Clark, B. R., Halpern, R. M. \& Smith, R. A. (1975). A fluorimetric method for quantitation in the picomole range of $\mathrm{N}_{1}$-methylnicotinamide and nicotinamide in serum. Analytical Biochemistry 68, 5461.

Clausen, H. H. (1977). Die Transketolase: ein Mittel zur Erkennung subklinischer und klinischer ThiaminMangelzustände beim Rind (Transketolase: an indicator of subclinical and clinical thiamin deficiencies in cattle). Deutsche Tierärtzliche Wochenschrift 84, 462-465.

Cooper, J. R., Nishino, K., Nishino, N. \& Piros, K. (1982). The enzymatic synthesis of thiamin triphosphate. Annals of the New' York Academy of Sciences 378, 177-187.

Cox. R. F. \& Mathias, A. P. (1969). Cytoplasmic effects of cortisol in liver. Biochemical Journal 115, $777-787$.

Cryer, D. (1985). Suspected cerebrocortical necrosis in the steenbok. Veterinary Record $117,474$.

Décombaz, J. \& Roux, L. (1982). Nicotinic acid increases glycogen utilization in exercise and reduces endurance. International Journal for Vitamin and Nutrition Research 52, 221.

Dennis, S. M., Arambel, M. J., Bartley, E. E., Riddell, D. O.\& Dayton, A. D. (1982). Effect of heated or unheated soybean meal with or without niacin on rumen protozoa. Journal of Dairy Science 65, 1643-1646.

Dickie, C. W., Nelson, R. J., Frazee, D. G., Krugman, L. D. \& Bronner, E. (1979). Polioencephalomalacia in range cattle. Journal of the American Veterinary Medical Association 175, 460-462.

Dreosti, I. E. (1984). Niacin. Journal of Food and Nutrition 41, 126-133.

Drozdowski, S. (1978). [Changes in the thiamin concentration in the rumen of cattle and sheep fed fodder containing easily digestible carbohydrates and urea.] Zeszyty Naukowe Szkoly Glownej Gospodarstwa Wiejskiego, Akademia Rolniczej, Warszawiej, Weterinaria 8, 21-38 (Chemical Abstracts 91, 191810a).

Dufva, G. S., Bartley, E. E., Dayton, A. D. \& Ridell, D. O. (1983). Effect of niacin supplementation on milk production and ketosis of dairy cattle. Journal of Dairy Science 66, 2329-2336.

Dufva, G. S., Bartley, E. E., Nagaraja, T. G., Dayton, A. D. \& Frey, R. A. (1984). Effect of dietary niacin supplementation on serum constituents of periparturient dairy cattle. American Journal of Veterinary Research 45, 1838-1841.

Dunlop, R. H., Bueno, L. \& Ruckebusch, Y. (1980). Slow wave spindle bursts in ovine polioencephalomalacia. In Metaholic Disorders in Farm Animals, IV International Conference on Production Disease in Farm Animals pp. 16-19 [D. Giesecke, G. Dirksen and M. Stangassinger, editors] München: Institut für Physiologie, Physiologische Chemie und Ernährungsphysiologie, Tierärztliche Fakultät der Universität München, FRG.

Edwin, E. E., Hebert, C. N., Jackman, R. \& Masterman, S. (1976b). Thiamine requirement of young ruminants. Journal of Agricultural Science 87, 679-688.

Edwin, E. E. \& Jackman, R. (1970). Thiaminase I in the development of cerebrocortical necrosis in sheep and cattle. Nature 228, 772-774. 
Edwin, E. E. \& Jackman, R. (1973). Ruminal thiaminase and tissue thiamine in cerebrocortical necrosis. Veterinary Record 92, 640-641.

Edwin, E. E. \& Jackman, R. (1982). Ruminant thiamine requirement in perspective. Veterinary Research Communications 5, 237-250.

Edwin, E. E., Jackman, R., Machin, A. F. \& Quick, M. P. (1976a). The importance of $\Delta^{\prime}$-pyroline in the aetiology of cerebrocortical necrosis. Biochemical and Biophysical Research Communications 70, 1190-1197.

Elbert, J., Daniel, H. \& Rehner, G. (1986). Intestinal uptake of nicotinic acid as a function of microclimate-pH. International Journal for Vitamin and Nutrition Research 56, 85-94.

Evans, W. C. (1975). Thiaminases and their effects on animals. Vilamins and Hormones 33, 467-504.

Federici, G. \& Genovesi, G. (1985). Polioencephalomalacia in ruminants. Obiettivi e Documenti Veterinari 7-8, 21-25.

Frank, O., Luisada-Opfer, A. F., Feingold, S. \& Baker, H. (1970). Vitamin-binding by human and some animal plasma proteins. Nutrition Reports International 6, 161-168.

Gerbaulet, B. M. (1979). Thiamin im Inhalt des Magendarmtraktes von Schafen (Thiamin content of the gastrointestinal tract of sheep). Thesis med. vet., Veterinary School Hannover.

Gey, K. F. \& Carlson, L. A. (editors) (1970). Metabolic Effects of Nicotinic Acid and its Derivatives. Bern: Hans Huber.

Giesecke, D. (1983). Nicotinsäure oder Nicotinamid? Biochemische Bedeutung der Vitamere und Wirkungsunterschiede im Stoffwechsel (Nicotinic acid or nicotinamide? Biochemical significance of the two vitamers and different metabolic effects). Übersichten zur Tierernährung 11, 133-154.

Grant, D. G. A. (1976). Cerebrocortical necrosis in a cattle feedlot. Rhodesian Veterinarian 7, $13-14$.

Grigat, G. A. \& Mathison, G. W. (1982). Thiamin supplementation of an all-concentrate diet for feedlot steers. Canadian Journal of Animal Science 62, 807-819.

Grigat, G. A. \& Mathison, G. W. (1983a). Thiamin and magnesium supplementation of all-concentrate diets for feedlot steers. Canadian Journal of Animal Science 63, 117-131.

Grigat, G. A. \& Mathison, G. W. (1983 b). A survey of the thiamin status of growing and fattening cattle in Alberta feedlots. Canadian Journal of Animal Science 63, 715-719.

Gross, C. J. \& Henderson, L. M. (1983). Digestion and absorption of NAD by the small intestine of the rat. Journal of Nutrition 113, 412-420.

Grosse-Holz, D. \& Harmeyer, J. (1988). Blut- und Milchparameter nach Nicotinsäurezulage bei laktierenden Kühen und Färsen (Blood and milk parameters in lactating cows with one or more lactations). Journal of Animal Physiology and Animal Nutrition 59, 182-191.

Gubler, C. J. (1984). Thiamin. In Handbook of Vitamins, Nutritional, Biochemical and Clinical Aspects, pp 245-297 [L. J. Machlin, editor]. New York: Marcel Dekker Inc.

Günther, K. D. (1987). Höhere Leistungen mit Vitamin $\mathbf{B}_{3}$ (Higher yields with vitamin $\mathbf{B}_{3}$ ). Ernährungsdienst 41, 6-7.

Gupta, G. C., Joshi, B. P. \& Rai, P. (1976). The levels of thiamine in the rumen fluid and blood serum in the spontaneous bovine rumen dysfunctions. Acta Veterinaria, Brno 45, 205-210.

Gustafsson, K. \& Kiessling, H. (1982). The mouse as a model for evaluation of hypotriglyceridemic drugs effects of nicotinic acid, clofibrate and ethyl-2-(-4-dibenzofuranoxyloxy)-2-methylpropionate on plasma lipoproteins. Versuchstierkunde 24, 271-277.

Hankes, L. V. (1984). Nicotinic acid and nicotinamide. In Handbook of Vitamins, Nutrional, Biochemical and Clinical Aspects, pp. 329-377 [L. J. Machlin, editor]. New York: Marcel Dekker Inc.

Harmeyer, J. \& Grabe, v. C. (1981). Der Einfluss hoher Leistungen auf die Ketogenese bei Milchkühen und die Wirkung einer Niacinzulage (Ketogenesis in high performing milking cows and the effect of a niacin supplement). Deutsche Tierärtzliche Wochenschrift 88, 401-404.

Harris, R. S., Jansen, B. C. P., Wuest, H. M., Lamden, M. P., Brown, G. M., Rogers, E. F., Unna. K. R. \& Sebrell, W. H. (1972). Thiamine. In The Vitamins, vol. V. pp. 97-164 [W. H. Sebrell and R. S. Harris, editors]. New York: Academic Press.

Haven, T. R., Caldwell, D. R. \& Jensen, R. (1983). Role of predominant rumen bacteria in the cause of polioencephalomalacia (cerebrocortical necrosis) in cattle. American Journal of Veterinary Research 44, $1451-1455$.

Hennig, A., Flachowsky, G. \& Löhnert, H.-J. (1976). Einfluss der Ernährung auf das Auftreten von zerebrokortikaler Nekrose bei jungen Wiederkäuern (Dietary effects on the development of cerebrocortical necrosis in young ruminants). Archiv für Tierernährung 26, 733 Abstr.

Höller. H. A. \& Breves, G. (1980). Vitamin $B_{1}$ in the sheep rumen. Tanzanian Veterinary Bulletin 2 , 31-37.

Höller, H., Breves, G., Lebzien, P. \& Rohr, K. (1985). Effect of monensin on net synthesis of thiamin and microbial protein in the rumen of cows Proceedings of the Nutrition Society 44, 146A.

Höller, H., Breves, G. \& Schmitt, R. (1979a). Disappearance from blood and urinary excretion of ${ }^{35} \mathrm{~S}-$ thiamin in sheep; a kinetic study. International Journal for Vitamin Nutrition and Research 49, 391-395.

Höller, H., Buchhop, K. \& Breves, G. (1979b). Untersuchungen zur Passage von Thiamin (Vit. B B $_{1}$ durch die Pansenwand von Schafen in vivo (Investigation on the passage of thiamin (Vit. $B_{1}$ ) across the rumen epithelium of sheep in vivo). Zentralblatt für Veterinärmedizin A 26, 841-846. 
Höller, H., Fecke, M. \& Schaller, K. (1977). Permeability to thiamin of the sheep rumen wall in vitro. Journal of Animal Science 44, 158-161.

Höller, H., Hübel, U. \& Breves, G. (1982). Untersuchungen zur Thiaminresorption aus dem Dickdarm von Schafen mit Hilfe der Colonperfusion (Investigation of thiamin absorption from the perfused colon of sheep). Zentralblatt für Veterinärmedizin A 29, 619-627.

Höller, H.. Schaller, K. \& Behrens, H. (1976). Untersuchungen über die Vitamin $B_{1}$-inaktivierende Wirkung in vitro von pflanzlichen Futtermitteln (Investigation of vitamin $B_{1}$ inactivation by plant feedstuffs). Deutsche Tierärtzliche Wochenschrift 83, 108-111.

Horner, J. L., Coppock, C. E., Schelling, G. T., Labore, J. M. \& Nave, D. H. (1986). Influence of niacin and whole cottonseed on intake, milk yield and composition, and systemic responses of dairy cows. Journal of Dairy Science 69, 3087-3093.

Hoyumpa, A. M. (1982). Characterization of normal intestinal thiamin transport in animals and man. Annals of the New York Academy of Sciences 378, 337-343.

Itokawa, Y., Inoue, K., Natori, Y., Okazaki, K. \& Fljiwara, M. (1972). Effect of thiamine on growth, tissue magnesium, thiamine levels and transketolase activity in magnesium deficient rats. Journal of Vitaminology 18, 159-164.

Jaster, E. H., Bell, D. F. \& McPherron, T. A. (1983a). Nicotinic acid and serum metabolite concentrations of lactating dairy cows fed supplemental niacin. Journal of Dairy Science 66, 1039-1045.

Jaster, E. H., Hartnell, G. F. \& Hutjens, F. (1983b). Effect of feeding supplemental niacin on milk production in six dairy herds. Journal of Dairy Science 66, 1046-1051.

Kazemi, M. \& Brent, B. E. (1985). Polioencephalomalacia in ruminants: activation of thiaminase I by its cosubstrates. Journal of Animal Science 61 (Suppl. 1), 456 Abstr.

Koike, M. \& Koike, K. (1982). Biochemical properties of mammalian 2-oxo acid dehydrogenase multienzyme complexes and clinical relevancy with chronic lactic acidosis. Annals of the New York Academy of Sciences 378, 225-235.

Kollenkirchen, U. (1987). Die Verteilung von Nikotinsäure und Nicotinamid im Pansensaft von Schafen (Partition of nicotinic acid and nicotinamide in rumen contents from sheep). Thesis rer, nat., University of Hannover.

Kollenkirchen, U. \& Harmeyer, J. (1986). Influence of dietary niacin on the outflow of niacin from the rumen of sheep. 6ih International Conference of Production Diseases in Farm Animals, Belfast pp. 137-140.

Kollenkirchen, U. \& Harmeyer, J. (1989a). Purification procedure for determination of niacin vitamers in gastrointestinal content and blood. Journal of Veterinary Medicine A 36, 247-252.

Kollenkirchen, U. \& Harmeyer, J. $(1989 b)$. Evaluation of elution parameters in reversed phase HPLC for the determination of niacin vitamers and metabolites. Journal of Veterinary Medicine A 36, 253-260.

Kronfeld, D. S. \& Raggi, F. (1964). Nicotinamide coenzyme concentration in mammary biopsy samples from ketotic cows. Biochemical Journal 90, 219-224.

Kung, L. J., Gubert, K. \& Huber, J. T. (1980). Supplemental niacin for lactating cows fed diets of natural protein or nonprotein nitrogen. Journal of Dairy Science 63, 2020-2025.

Laarsveld, B. (1983). Ketosis update. Fourth Western Nutrition Conference, pp. 229-236.

Lafrance, L., Routhier, D., Tetu, C. \& Tetu, B. (1979). Effects of noradrenaline and nicotinic acid on plasma free fatty acids and oxygen consumption in cold-adapted rats. Canadian Journal of Physiology and Pharmacology 57, 725-730.

Latham, M. C. (1967). Present knowledge of thiamine. In Present Knowledge in Nutrition. 25th Anniversary of the Nutrition Foundation, 3rd ed., pp. 55-60. New York.

Lebzien, P., Rohr, K., Breves, G. \& Höller, H. (1986). Untersuchungen über den Einfluss von Rumensin (Monensin-Natrium) auf die Stickstoffumsetzungen und die Thiaminnettosynthese in den Vormägen von Wiederkäuern (Investigation of the effect of rumensin (monensin-sodium salt) on nitrogen metabolism and net synthesis of thiamin in the forestomach of ruminants). Journal of Animal Physiology and Animal Nutrition 55, $177-186$.

Loew, F. M. (1975). A thiamin-responsive polioencephalomalacia in tropical and nontropical livestock production systems. World Review of Nutrition and Dietetics 20, 168-183.

Loew, F. M. \& Dunlop, R. H. (1972a). Blood thiamin in bovine polioencephalomalacia. Canadian Journal of Comparative Medicine 36, 345-347.

Loew, F. M. \& Dunlop, R. H. (1972 b). Induction of thiamin inadequacy and polioencephalomalacia in adult sheep with Amprolium. American Journal of Veterinary Research 33, 2195-2205.

McCreanor, G. M. \& Bender, D. A. (1986). The metabolism of high intakes of tryptophan, nicctinamide and nicotinic acid in the rat. British Journal of Nutrition 56, 577-586.

McDonald, J. W. (1982). Mortality and illthrift associated with thiamine deficiency in lambs. Australian Veterinary Journal 58, 212-213.

Mann, S. O., Wilson, A. B., Barr, M., Lawson, W. J., Duncan, L., Smith, A., Fell, B. F., Walker, H. F. \& MacDonald, D. C. (1983). Thiaminase activity in the gut of cobalt-deficient sheep. Australian Journal of Agricultural Research 34, 211-218.

Markson, L. M., Edwin, E. E., Lewis, G. \& Richardson, C. (1974). The production of cerebrocortical necrosis in ruminant calves by the intraruminal administration of Amprolium. British Veterinary Journal 130. 9-16. 
Mathison, G. W. (1986). B-vitamins, choline, inositol and paraaminobenzoic acid for ruminants. 2/st Annual Pacific Northiest Animal Nutrition Conference, Vancouver pp. 107-157.

Menke, K. H. (1973). Vitaminsynthesen im Pansen (Vitamin syntheses in the rumen). In Biologie und Biochemie der mikrobiellen Verdauung (Biology and Biochemistry of Microbial Digestion), pp. 235-255 [D. Giesecke and H. K. Henderickx, editors]. Munich: BLV Verlagsgesellschaft.

Miller, B. L., Goodrich, R. D. \& Meiske, J. C. (1983a). Effects of chlortetracycline on B-vitamin production in steers, Journal of Animal Science 57 (Suppl. 1), 453-454 Abstr.

Miller, B. L., Meiske, J. C. \& Goodrich, R. D. (1986a). Effects of dietary additives on B-vitamin production and absorption in steers. Journal of Animal Science 62, 484-496.

Miller, B. L., Meiske, J. C. \& Goodrich, R. D. (1986h). Effects of grain source and concentrate level on B-vitamin production and absorption in steers. Journal of Animal Science 62, 473-483.

Miller, B. L., Plegge, S. D., Goodrich, R. D. \& Meiske, J. C. (1983b). Influence of dietary grain level on production and absorption of B-vitamins in beef steers. Minnesota Beef Report B 299, 46.

Miller, B. L.. Plegge, S. D., Goodrich, R. D. \& Meiske, J. C. (1983c). Influence of grain source on production and absorption of B-vitamins in beef steers. Minnesota Beef Report B 299, 1-3.

Miller, B. L., Plegge, S. D., Goodrich, R. D. \& Meiske, J. C. (1983d). Influence of Monensin on B-vitamin synthesis and absorption in beef steers. Minnesota Becf Report B 299, 7..9.

Morgan, K. T.\& Lawson, G. H. K. (1974). Thiaminase type I-producing bacilli and ovine polioencephalomalacia. Veterinary Record 95, 361-363.

Moss, G. (1964). The contribution of the hexose monophosphate shunt to cerebral glucose metabolism. Diabetes $13,585-591$.

Mueller, R. E. \& Asplund, J. M. (1981). Evidence in the ovine that polioencephalomalacia is not a result of an uncomplicated thiamin deficiency. Nutrition Reports International 24, 95-104.

Muller, L. D., Heinrichs, A. J., Cooper, J. B. \& Atkin, Y. H. (1986). Supplemental niacin for lactating cows during summer feeding. Journal of Dairy Science 69, 1416-1420.

Naga, M. A., Harmeyer, J. H., Höller, H. \& Schaller, K. (1975). Suspected "B"-vitamin deficiency of sheep fed a protein-free urea containing purified diet. Journal of Animal Science 40, 1192-1198.

Nakajima, N. (1984). Studies on the metabolism of thiamine in cattle: blood level and urinary excretion after intravenous administration of thiamine preparations. Journal of the Japanese Veterinary Medical Association 37, 99-103.

Nishino, K. \& Itokawa, Y. (1983). Enzyme system involved in the synthesis of thiamin triphosphate. Journal of Biological Chemistry 258, 11871-11878.

Ogawa, K., Sakai, M. \& Inomata, K. (1982). Recent findings on ultracytochemistry of thiamin phosphatases. Annals of the New York Academy of Sciences 378, 188-214.

Oracovà, V. \& Cörner, F. (1960). Teneur du lait de brebis en vitamines $A_{1}, B_{1}, B_{2}$ (Vitamin $A_{1}, B_{1}$ and $B_{2}$ content in ewe's milk.) Annales de la Nutrition et d'Alimentation 14, 151-160.

Pike, R. L. \& Brown, M. L. (1975). Nutrition: An Integrated Approach 2nd ed., p. 95. New York: John Wiley and Sons.

Plaitakis. A., Hwang, E. C., Van Woert, M. H., Szilagyi, P. I. A. \& Berl, S. (1982). Effect of thiamin deficiency on brain neurotransmitter systems. Annals of the New' York Academy of Sciences 378, 367.381

Pohlenz, J. F. L. (1975a). Experimentelle Untersuchungen zur Vitamin B, Hypovitaminose bei Wiederkäuern (Experimental investigations of vitamin $\mathbf{B}_{1}$ hypovitaminosis of ruminants). Habilitationsschrift, Veterinary Faculty, University of Zurich.

Pohlenz, J. F. L. (1975b). Zur Thiaminversorgung von Mastkälbern (The supply of thiamin in fattening calves). Übersichten zur Tierernährung 3, 301.

Porter, J. W. G. (1961). Vitamin synthesis in the rumen. In Digestive Physiology and Nutrition of the Ruminant, pp. 226-234 [D. Lewis, editor]. London: Butterworth.

Rammell, C. G. \& Hill, J. H. (1986). A review of thiamine deficiency and its diagnosis, especialy in ruminants. New Zealand Veterinary Journal 34, $202-204$.

Reid, I. M. \& Treacher, R. J. (1983). Niacin in the dairy cow. Roche Brochure, 15 pp. (Reprinted from Roche vitamin symposium, 1982).

Riddell, D. O., Arambel, M. J., Dufva, G. S., Bartley, E. E., Dayton, A. D., Nagaraja, T. G. \& Miller, G. W. (1985). Ruminal synthesis and degradation of niacin and its concentration in cattle blood. Nutrition Reports International 31, 407-413.

Riddell, D. O., Bartley, E. E. \& Dayton, A. D. (1980). Effect of nicotinic acid on rumen fermentation in vitro and in vivo. Journal of Dairy Science 63, 1429.1435.

Riddell, D. O., Bartley. E. E. \& Dayton, A. D. (1981). Effect of nicotinic acid on microbial protein synthesis in vitro and on dairy cattle growth and milk production. Journal of Dairy Science 64. 782. 791.

Robinson, J. R. (1986). Niacin in beef cattle nutrition. Animal Nutrition and Health 41. 9-10.

Rogers, E. F. (1982). General discussion of antithiamin compounds and thiamin antagonists. Annals of the New York Academy of Sciences 378, 157-160.

Rohr, K., Lepzien, P., Schafft, H. \& Schulz, E. (1986). Prediction of duodenal fow of non-ammonia nitrogen and amino acid nitrogen in dairy cows. Lives/ock Production Science 14, 29-40.

Ruegsegger, G. J. \& Schultz, L. H. (1986). Use of a combination of propylene glycol and niacin for subclinical ketosis. Journal of Dairy Science 69, 1411-1415. 
Säuberlich. H. E. (1981). Recent advances in analytical methods for the water-soluble vitamins. In Nutrition in Health and International Development: Symposia from the XIIth International Congress of Nutrition, pp. 151-157. New York: Alan R. Liss.

Schaetzel, W. P. \& Johnson, D. E. (1981). Nicotinic acid and dilution rate effects on in vitro fermentation efficiency. Journal of Animal Science 53, 1104-1108.

Schuette, S. A. \& Rose, R. C. (1983). Nicotinamide uptake and metabolism by chick intestine. American Journal of Physiology 245, S31-538.

Schultz, L. H. (1971). Management and nutritional aspects of ketosis. Journal of Dairy Science 54, 962-973.

Schultz, L. H. (1983). Niacin in dairy rations. Official Proceedings, 18th Annual Pacific Northu'est Animal Nutrition Conference pp. 69-76. Corvallis, OR: Oregon State University.

Schussler, S. L., Fahey, G. C., Robinson, J. B., Masters, S. S., Loerch, S. C. \& Spears, J. W. (1978). The effect of supplemental niacin on in vitro cellulose digestion and protein synthesis. International Journal for Vitamin and Nutrition and Research 48, 359-367.

Schwab, C. G. (1983). Supplemental niacin for cows in early lactation. New England Dairy Feed Conference, pp. 1-7. Concord, NH: University of New Hampshire.

Shibata, K. (1987). Blood pyridine nucleotide levels reflect niacin equivalent intake in humans. Journal of Clinical Biochemistry and Nutrition $43,37-45$.

Shibata, K., Kawada, T. \& Iwai, K. (1987). Microdetermination of $\mathrm{N}_{1}$-methyl-2-pyridone-5-carboxamide, a major metabolite of nicotinic acid and nicotinamide, in urine by high-performance liquid chromatography. Journal of Chromatography Biomedical Applications 417, 173-177.

Shibata, K., Tanaka, K. \& Murata, K. (1986). Efficiency of exogenous quinolinic acid as niacin in rats. Agricultural and Biological Chemistry 50, 2025-2032.

Shields, D. R., Schaefer, D. M. \& Perry, T. W. (1983). Influence and niacin supplementation and nitrogen source on rumen microbial fermentation. Journal of Animal Science 57, 1576-1583.

Sipöcz, J. \& Schmidt, J. (1985). Wirkung einer Niacin (Nikotinsäure)-Zulage auf Milchleistung, Milchzusammensetzung und einige Parameter des Blutserums (Effect of a niacin (nicotinic acid) supplement on milk production, milk composition and some blood parameters). Kraftfutter 68, 253-256.

Smith, R. W. \& Glascock, R. F. (1969). The effects of acetate and of pyruvate on the pathways of glucose catabolism in lactating mammary tissue. II. Sheep tissue. Journal of Dairy Research 36, 469-478.

Spector, R. (1982). Thiamin homeostasis in the central nervous system. Annals of the Neu' York Academy of Sciences 378, 344-354.

Stanulovic, M. \& Chaykin, S. (1971). Metabolic origins of the pyridones of $N_{1}$-methylnicotinamide in man and rat. Archives of Biochemistry and Biophysics 145, 35-42.

Steinberg, W. \& Kaufmann, W. (1977). Untersuchungen zur bakteriellen Thiaminsynthese in den Vormägen von Milchkühen (Investigation of bacterial synthesis of thiamin in the forestomach of milking cows). Zeitschrift für Tierphysiologie, Tierernährung und Futtermittelkunde 39, 289-301.

Steinberg. W., Kaufmann, W. \& Hagemeister, H. (1977). Messungen zur Bestimmung der Resorption von Thiamin in den Vormägen und im Darm von Milchkühen (Experimental studies of thiamin absorption from forestomach and intestine of milking cows). Zeitschrift für Tierphysiologie, Tierernährung und Futtermittelkunde 39, 282-288.

Suzuki, K. \& Ooba, J. I. (1973). Reversible inactivation of extracellular thiaminase I in Bacillus thiaminolyticus. I. Inactivation by the primary substrate and reactivation by the secondary substrate. Biochimica et Biophysica Acta 293, $111-117$.

Tanwar, R. K. (1987). Polioencephalomalacia, an emerging disease of goats. Indian Journal of Animal Science 57, $1-4$.

Thomas, K. W. (1986a). The effect of thiaminase-induced subclinical thiamine deficiency on growth of weaner sheep. Veterinary Research Communications 10, 125-141.

Thomas, K. W. (1986 h). Oral treatment of polioencephalomalacia and subclinical thiamine deficiency with thiamine propyl disulphide and thiamine hydrochloride. Journal of Veterinary Pharmacology and Therapy 9. 402-411.

Thornber, E. J., Dunlop, R. H. \& Gawthorne. J. M. (1980). Thiamin deficiency in the lamb. Journal of Neurochemisiry 35, 713-717.

Thornber, E. J.. Dunlop, R. H., Gawthorne, J. M. \& Huxtable, C. R. (1981). Induced thiamin deficiency in lambs. Australian Veterinary Journal 57, 21-26.

Van Soest. P. J. (1982). Nutritional Ecology of the Ruminant, pp. 241-243, Portland, OR: Durham and Downey.

Vincke, B. J., Devleeschouwer, M. J., Dony, J. \& Patriarche, G. (1984). Analytical determination of nicotinamide using bacterial electrodes. International Journal of Pharmacy 21, 265-275.

Virtanen, A. 1. (1963). Produktion der Kuhmilch ohne Protein mit Harnstoff und Ammoniumsalzen als Stickstoffquelle und gereinigten Kohlenhydraten als Energiequelle (Production of cows' milk in the absence of feed protein with urea and ammonium salts as nitrogen sources and with purified carbohydrates as energy source). Biochemische Zeitschrift 338, 443-453.

Warner, A. C. 1. (1964). The breakdown of asparagine, glutamine, and other amides by microorganisms from the sheep's rumen. Journal of Biological Science 17, 170-182. 
Wilson, A. B., Mann, S. O., Barr, M. \& Lawson, W. J. (1984). Asymptomatic thiaminase activity in sheep gut. Microbios Letters 26, 57-61.

Yamada, O., Shin, M., Sano, K. \& Umezawa, C. (1983). Effect of leucine and $\alpha$-ketoisocaproic acid on NAD biosynthesis from tryptophan or nicotinic acid in the isolated rat liver cells. International Journal for Vitamin and Nutrition Research 53, 184-191.

Yano, H. \& Kawashima, R. (1977). Effects of thiamine administration on blood lactic acid concentration and mineral metabolism in sheep. Journal of Nutritional Science and Vitaminology 23, 491-496.

Yeh, Y. Y. (1976). Nicotinic acid reverses fasting ketosis by lowering the level of cyclic AMP. Life Sciences 18. 33-38.

Yeh, Y. Y. (1979). The opposing effects of nicotinic acid and dibutyryl cyclic adenosine 3.5-monophosphate on ketogenesis in isolated rat hepatocytes. Journal of Nutrition 109, 110-118.

Zinn, R. A., Owens, F. N., Stuart, R. L., Dunbar, J. R. \& Norman, B. B. (1987). B-vitamin supplementation of diets for feedlot calves. Journal of Animal Science 65, 267-277.

Zintzen, H. (1973). Vitamin $B_{1}$ (Thiamin) in der Ernährung des Wiederkäuers (Vitamin $B_{1}$ (thiamin) in ruminant nutrition. Übersichten zur Tierernährung 1, 273-323.

Zöllner, N. (1971). Effect of nicotinic acid and some derivatives on blood levels of triglycerides of man. In Metabolic Effects of Nicotinic Acid and its Derivatives, pp. 427-430 [K. F. Gey, and L. A. Carlson, editors]. Bern: Hans Huber.

Zoltewicz, J. A., Kauffman, G. \& Uray, G. (1982). Nucleophilic substitution reactions of thiamin and its derivatives. Annals of the New' York Academy of Sciences 378, 7-13.

Zweiacker, F. (1982). Niacin in der Fütterung von Milchkühen (Feed niacin for milking cows). Kraftfutter 65, 336-338. 